\title{
Analysis of Sensitivity of Simulated Recharge to Selected Parameters for Seven Watersheds Modeled Using the Precipitation-Runoff Modeling System
}

LOCATION OF SEVEN WATERSHEDS EXAMINED IN THIS STUDY.

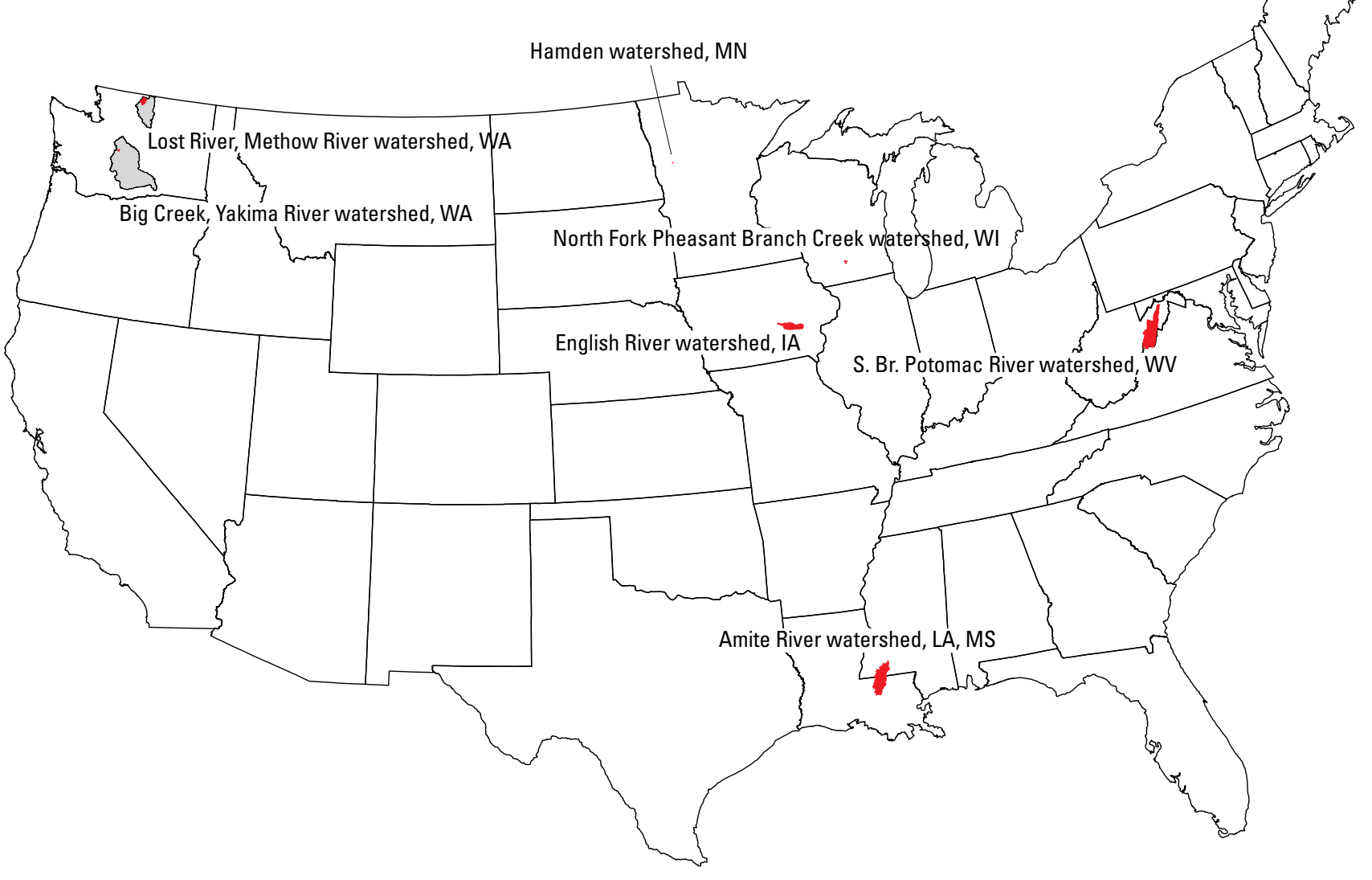

Scientific Investigations Report 2006-5041 


\section{Analysis of Sensitivity of Simulated Recharge to Selected Parameters for Seven Watersheds Modeled Using the Precipitation-Runoff Modeling System}

By D. Matthew Ely

Scientific Investigations Report 2006-5041 


\title{
U.S. Department of the Interior \\ Gale A. Norton, Secretary \\ U.S. Geological Survey \\ P. Patrick Leahy, Acting Director
}

\section{U.S. Geological Survey, Reston, Virginia: 2006}

\author{
For sale by U.S. Geological Survey, Information Services \\ Box 25286, Denver Federal Center \\ Denver, CO 80225 \\ For more information about the USGS and its products: \\ Telephone: 1-888-ASK-USGS \\ World Wide Web: http://www.usgs.gov/
}

\footnotetext{
Any use of trade, product, or firm names in this publication is for descriptive purposes only and does not imply endorsement by the U.S. Government.

Although this report is in the public domain, permission must be secured from the individual copyright owners to reproduce any copyrighted materials contained within this report.

Suggested citation:

Ely, D.M., 2006, Analysis of sensitivity of simulated recharge to selected parameters for seven watersheds modeled using the precipitation-runoff modeling system: U.S. Geological Survey Scientific Investigations Report 2006-5041, $21 \mathrm{p}$.
} 


\section{Contents}

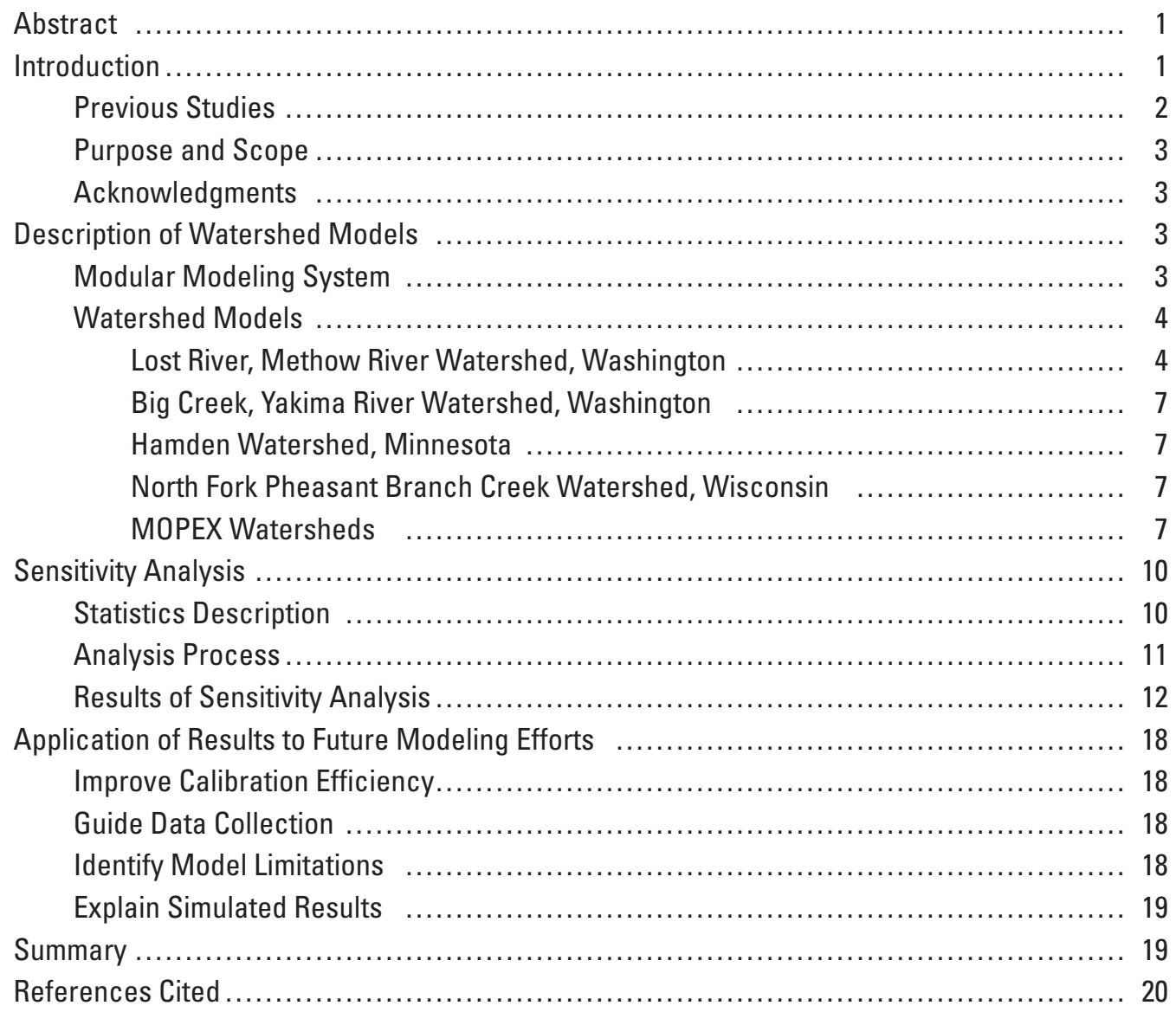




\section{Figures}

Figure 1. Schematic diagram of the conceptual Precipitation-Runoff Modeling System..... 4

Figure 2. Map showing locations of seven watersheds examined for sensitivity of simulated ground-water recharge.

Figure 3. Maps showing locations of Lost River, Methow River watershed and Big Creek, Yakima River watershed, Washington

Figure 4. Maps showing locations of Hamden watershed, Minnesota and North Fork Pheasant Branch Creek watershed near Middleton, Wisconsin

Figure 5. Maps showing locations of the Amite River watershed, Louisiana and Mississippi; English River watershed, lowa; and South Branch Potomac River watershed, West Virginia

Figure 6. Graphs showing dimensionless scaled sensitivities of the five most significant model parameters, in descending order, for seven watershed models

Figure 7. Graph showing normalized composite scaled sensitivities of model parameters for the Lost River and Big Creek watersheds, Washington

Figure 8. Graph showing normalized composite scaled sensitivities of model parameters for the Hamden watershed, Minnesota

Figure 9. Graph showing normalized composite scaled sensitivities of model parameters for the North Fork Pheasant Branch watershed, Wisconsin

Figure 10. Graph showing normalized composite scaled sensitivities of model parameters for the Amite River watershed, Louisiana and Mississippi; English River watershed, lowa; and South Branch Potomac River watershed, West Virginia

\section{Tables}

Table 1. Summary of watershed characteristics and simulation periods for seven watershed models

Table 2. Description of Precipitation-Runoff Modeling System parameters used in sensitivity analysis for the seven watershed models

Table 3. Parameter correlation coefficients greater than 0.85 or less than -0.85 for seven watershed models 


\section{Conversion Factors, Datums, and Acronyms and Abbreviations}

Conversion Factors

\begin{tabular}{lcl}
\hline Multiply & By & To obtain \\
\hline cubic foot per second $\left(\mathrm{ft}^{3} / \mathrm{s}\right)$ & 0.02832 & cubic meter per second \\
inch (in.) & 2.54 & centimeter \\
inch (in.) & 25.4 & millimeter \\
inch per day (in/d) & 25.4 & millimeter per day \\
inch per year (in/yr) & 25.4 & millimeter per year \\
foot (ft) & 0.3048 & meter \\
mile (mi) & 1.609 & kilometer \\
square mile $\left(\mathrm{mi}^{2}\right)$ & 2.590 & square kilometer \\
\hline
\end{tabular}

Temperature in degrees Fahrenheit $\left({ }^{\circ} \mathrm{F}\right)$ may be converted to degrees Celsius $\left({ }^{\circ} \mathrm{C}\right)$ as follows:

$$
{ }^{\circ} \mathrm{C}=\left({ }^{\circ} \mathrm{F}-32\right) / 1.8 \text {. }
$$

Datums

Vertical coordinate information is referenced to the National Geodetic Vertical Datum of 1929 (NGVD29), referred to in this report as "sea level."

Horizontal coordinate information is referenced to the North American Datum of 1983 (NAD83).

Altitude, as used in this report, refers to distance above or below sea level.

Acronyms and Abbreviations

\begin{tabular}{ll}
\hline Acronym and Abbreviation & Meaning or definition \\
\hline AET & actual evapotranspiration \\
CSS & composite scaled sensitivities \\
DSS & dimensionless scaled sensitivities \\
ET & evapotranspiration \\
HRU & hydrologic response unit \\
MMS & Modular Modeling System \\
MOPEX & Model Parameter Estimation Experiment \\
PRMS & Precipitation-Runoff Modeling System \\
USGS & U.S. Geological Survey \\
VOII & value of improved information \\
\hline
\end{tabular}


This page intentionally left blank 


\title{
Analysis of Sensitivity of Simulated Recharge to Selected Parameters for Seven Watersheds Modeled Using the Precipitation-Runoff Modeling System
}

\author{
By D. Matthew Ely
}

\section{Abstract}

Recharge is a vital component of the ground-water budget and methods for estimating it range from extremely complex to relatively simple. The most commonly used techniques, however, are limited by the scale of application. One method that can be used to estimate ground-water recharge includes process-based models that compute distributed water budgets on a watershed scale. These models should be evaluated to determine which model parameters are the dominant controls in determining ground-water recharge.

Seven existing watershed models from different humid regions of the United States were chosen to analyze the sensitivity of simulated recharge to model parameters. Parameter sensitivities were determined using a nonlinear regression computer program to generate a suite of diagnostic statistics. The statistics identify model parameters that have the greatest effect on simulated ground-water recharge and that compare and contrast the hydrologic system responses to those parameters.

Simulated recharge in the Lost River and Big Creek watersheds in Washington State was sensitive to small changes in air temperature. The Hamden watershed model in west-central Minnesota was developed to investigate the relations that wetlands and other landscape features have with runoff processes. Excess soil moisture in the Hamden watershed simulation was preferentially routed to wetlands, instead of to the ground-water system, resulting in little sensitivity of any parameters to recharge. Simulated recharge in the North Fork Pheasant Branch watershed, Wisconsin, demonstrated the greatest sensitivity to parameters related to evapotranspiration. Three watersheds were simulated as part of the Model Parameter Estimation Experiment (MOPEX). Parameter sensitivities for the MOPEX watersheds, Amite River, Louisiana and Mississippi, English River, Iowa, and South Branch Potomac River, West Virginia, were similar and most sensitive to small changes in air temperature and a userdefined flow routing parameter.
Although the primary objective of this study was to identify, by geographic region, the importance of the parameter value to the simulation of ground-water recharge, the secondary objectives proved valuable for future modeling efforts. The value of a rigorous sensitivity analysis can (1) make the calibration process more efficient, (2) guide additional data collection, (3) identify model limitations, and (4) explain simulated results.

\section{Introduction}

Recharge is a vital component of the ground-water budget. As competition grows for limited water resources, water managers increasingly consider the ground-water system as a source for possible development. To aid in the decision-making process, managers look to numerical models as management tools. Recharge rates used in the numerical models are usually extremely important in calculating simulation results, and therefore, considerable effort must be spent quantifying the value.

Ground-water recharge estimation methods vary from extremely complex to relatively simple. Variably saturated flow models, such as VS2DT (Healy, 1990; Lappala and others, 1987), VS2DH (Healy and Ronan, 1996), or HYDRUS-2D (Simunek and others, 1999), that solve the Richards' Equation for fluid flow are best suited to estimate recharge, but they require soil parameter data that are generally unavailable (Bauer and Vaccaro, 1987) or are too costly to obtain. Simpler methods, such as empirical relations based on precipitation and surficial geology (Woodward and others, 1995; Drost and others, 1999) or hydrograph separation (Rorabaugh, 1964; Rutledge and Daniel, 1994; Rutledge, 1998), do not characterize fluid flow processes. A ground-water budget is a useful tool but many components of the budget, such as precipitation, streamflow, and evapotranspiration (ET), must be measured directly. Methods using geochemical or radioisotope techniques can be costly and are best suited for long-term average recharge rates. Scanlon and others (2002) provide a comprehensive review of these and other recharge estimation methods. 
The scale of application also limits these commonly used techniques. The methods simulate either at a point or site scale and must be extrapolated to a larger area or they simulate a single value for a large area, limiting the option to accurately scale down to a local area or to distribute recharge estimates spatially.

Another method for estimating ground-water recharge includes process-based models that compute distributed water budgets on a watershed scale (Leavesley and others, 1983; Bauer and Vaccaro, 1987). Cherkauer (2004) demonstrated that the method calculates accurate recharge rates at varying scales using readily available databases. The recharge component of these spatially distributed water budgets can then be used as input to numerical ground-water flow models (Hunt and others, 2001). These watershed models should be evaluated to determine which model parameters are the dominant controls in determining ground-water recharge. Determining which watershed-model parameters control recharge estimates would allow hydrologists to focus on compiling only the most relevant data in studies of regional ground-water recharge.

The U.S. Geological Survey (USGS) analyzed the sensitivity of simulated ground-water recharge to selected parameters in seven different applications of a precipitationrunoff watershed model representing distinctly different watersheds in humid regions of the United States. The objectives of the study were to determine: (1) which watershed-model parameters were the dominant controls in determining ground-water recharge; (2) if regional differences were in the sensitivity of ground-water recharge to watershedmodel parameters; (3) if specific computer models used to simulate recharge affect parameter sensitivities; and (4) if objectives and approach of a study can affect ground-water recharge estimates and parameter sensitivities.

The study evaluated 16 watershed-model parameters common to all 7 watersheds, and an additional parameter common to 2 of the watersheds. Parameter sensitivities were determined using a nonlinear regression computer program to generate a suite of diagnostic statistics. These diagnostic statistics identify model parameters that are most important (greatest effect on simulated result [recharge]) for determining ground-water recharge, and compare and contrast the response of different types of hydrologic systems to those parameters. The study also assessed the usefulness of this type of sensitivity analysis in planning and carrying out watershed model studies and explaining the results.

\section{Previous Studies}

Most modelers understand the importance of a sensitivity analysis in any modeling effort. Research on watershed modeling has advanced considerably, along with the awareness that computer-model algorithms and their associated model parameter sets are not unique and that infinite plausible mathematical representations exist (Vogel and Sankarasubramanian, 2003). Christiaens and Feyen (2002) provide a short overview of available sensitivity-analysis methods. However, these methods are not widely applied in watershed modeling.

Vogel and Sankarasubramanian (2003) used a generalized sensitivity analysis to derive analytical relations between the input (precipitation), output (streamflow), model error, and model parameters. They determined that a watershed model could be validated by reproducing those relations. Samanta and McKay (2003) used a Monte Carlo sampling strategy to determine the sensitivity of the model's streamflow output to different values of hydrologically relevant parameters.

Downer and Ogden (2003) examined the effects of model complexity and parameter assignment in a coupled surface/subsurface hydrologic model and determined the model was insensitive to soil depth and most sensitive to saturated hydraulic conductivity. Martinez and others (2001) did a sensitivity analysis to determine the effects of increasing the number of soil layers in a land surface-atmosphere model on the water budget. The conclusions of Martinez and others (2001) differed from those of Downer and Ogden (2003). Martinez and others determined that (1) the water budget was sensitive to the number of layers in the soil profile during wet conditions, and (2) the sensitivity to the number of soil layers greatly exceeded the sensitivity to the range of saturated hydraulic conductivity. The conflicting results suggest that the role parameters play in different models and settings needs to be evaluated.

Christiaens and Feyen (2002) used the Latin hypercube approach to qualify and quantify uncertainty and sensitivity measures in the spatially distributed hydrological model. They evaluated the sensitivity of streamflow discharge, average soil water content, and ground-water elevation to soil hydraulic parameters. They determined that the correlation among parameters added significant complexity to the assessment of uncertainty and sensitivity.

Yobbi (2000) used 91 recharge-parameter zones derived from a surface-water model as input to a coupled groundwater flow model. A nonlinear least-squares regression method determined that the model simulations were relatively insensitive to any one recharge-parameter zone.

The various approaches, limited scope (one watershed simulation per analysis), and differing results make it impossible to draw broad conclusions concerning recharge sensitivity to parameters. The study presented in this report differs significantly by using a standard method to evaluate the parameters important to ground-water recharge in seven different humid region watershed models and attempting to draw general conclusions from the diagnostic statistics. 


\section{Purpose and Scope}

This report documents an analysis of the sensitivity of ground-water recharge to selected parameters in seven watershed models. The report (1) describes the seven watershed models, the nonlinear regression model used to calculate diagnostic statistics, and the sensitivity-analysis process, (2) evaluates the recharge-parameter sensitivities, (3) assesses the effects of regional differences, type of watershed model, and study objectives and approaches on sensitivity, and (4) discusses the importance of a rigorous sensitivity analysis. The analysis for each watershed model covered a 3-year simulation period.

The results of this study can help focus data-collection efforts in future studies that require watershed-scale estimates of ground-water recharge. An understanding of parameter sensitivities and correlations will make the calibration process more efficient. Future studies also could benefit from an understanding of regional differences in ground-water recharge processes and of the effect of the specific model code and objectives on parameter sensitivities.

\section{Acknowledgments}

The USGS Ground-Water Resources Program funded this work. Mark Mastin and John Vaccaro, USGS, Tacoma, Wash., Kevin Vining, USGS, Bismarck, N. Dak., Randall Hunt, USGS, Madison, Wis., and George Leavesley and Steve Markstrom, USGS, Denver, Colo., generously submitted their watershed models for evaluation in this study.

\section{Description of Watershed Models}

Existing watershed models for seven watersheds were examined for this study: Lost River and Big Creek watersheds (Washington State), Hamden watershed (Minnesota), North Fork Pheasant Branch watershed (Wisconsin), Amite River watershed (Mississippi and Louisiana), English River watershed (Iowa), and South Branch Potomac River watershed (West Virginia). The watersheds were simulated using a watershed model, or precipitation-runoff model, that simulates runoff and ground-water recharge from precipitation and air temperature inputs. The purpose and scope of the different watershed modeling projects, as well as the method of construction and calibration varied significantly.

\section{Modular Modeling System}

The USGS Modular Modeling System (MMS), developed by Leavesley and others (1996), was used for the watershed-simulation component of the study. MMS is an integrated system of computer software developed to provide a framework for the development and application of models to simulate various hydrologic processes. Existing models can be modularized and brought into MMS. Modularization allows the user to select appropriate algorithms (modules) or develop new modules to create an optimal model for the desired application.

The Precipitation-Runoff Modeling System (PRMS) (Leavesley and others, 1983) was the model incorporated into MMS for the analysis of recharge-parameter sensitivities. PRMS is a deterministic, process-based, distributedparameter modeling system designed to analyze the effects of precipitation, climate, and land use on streamflow and general watershed hydrology (Leavesley and others, 1983). Land units of similar hydrologic response to precipitation and temperature, known as hydrologic response units (HRU), are conceptualized as an interconnected series of reservoirs whose collective output produces the total hydrologic response (fig. 1). These reservoirs include interception storage in the vegetation canopy, storage in the soil zone, subsurface storage between the surface of a watershed and the water table, and ground-water storage. PRMS considers subsurface flow (or interflow) to be relatively rapid movement of water from the unsaturated zone to a stream channel. Flow to a groundwater reservoir comes from a soil zone and a subsurface reservoir. The ground-water reservoir is considered the source of all baseflow. The movement of water from one reservoir to another is computed throughout the simulation and is controlled by user-specified parameters. The application of the model for this study was run on a daily time step. The system inputs included daily precipitation and daily maximum and minimum air temperature. Streamflow at a watershed outlet is the sum of area-weighted surface, subsurface, and ground-water flows in the watershed.

Simulated soil water in excess of field capacity first satisfies the ground-water reservoir based on a user-specified recharge rate. When the percolating moisture exceeds this daily recharge rate, the excess soil water goes to the subsurface reservoir. Excess moisture in the subsurface reservoir either percolates to a ground-water reservoir or flows to a discharge point above the water table. 


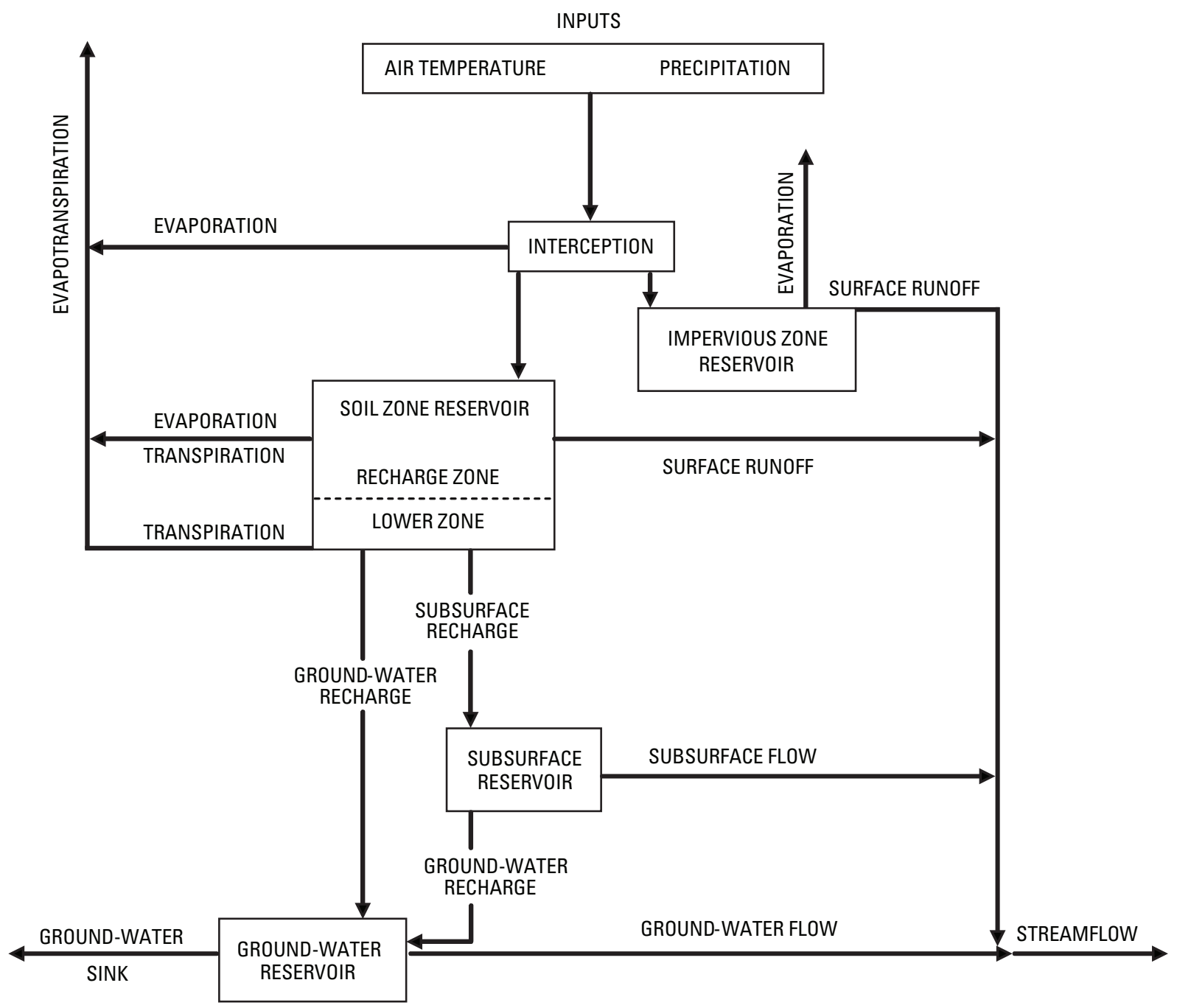

Figure 1. Conceptual Precipitation-Runoff Modeling System.

\section{Watershed Models}

Seven existing watershed models were examined for this study (fig. 2). The purpose and scope of the different watershed modeling projects, as well as the method of construction and calibration varied significantly. No attempt was made to recalibrate the models or to evaluate the statistical measures of model fit. Selected watershed characteristics are presented in table 1.

\section{Lost River, Methow River Watershed, Washington}

Lost River watershed occupies the northwestern part of the Methow River watershed in north-central Washington State and covers an area of about $167 \mathrm{mi}^{2}$ (fig. 3, table 1). Lost River originates in the Cascade Range and flows south to the confluence of the Methow River. Topography in the Lost River watershed ranges from peaks reaching $8,700 \mathrm{ft}$ above sea level along the Cascade crest down to 2,370 $\mathrm{ft}$ at the confluence with the Methow River. Lost River watershed average precipitation for the simulation period (1995-98), as computed by the model, was about $55 \mathrm{in} / \mathrm{yr}$, which accumulates as snow from late autumn to early spring. Annual mean streamflow in 2002 was $265 \mathrm{ft}^{3} / \mathrm{s}$ and the highest streamflow resulted from spring snowmelt.

Lost River watershed was simulated as part of the Methow River watershed (Ely and Risley, 2001; Ely, 2003). The purpose of the watershed model was to simulate current and natural streamflow conditions. The model was calibrated using streamflow data from seven steamflow-gaging stations, including Lost River near Mazama (USGS streamflow-gaging station 12447370). 
LOCATION OF SEVEN WATERSHEDS EXAMINED IN THIS STUDY.

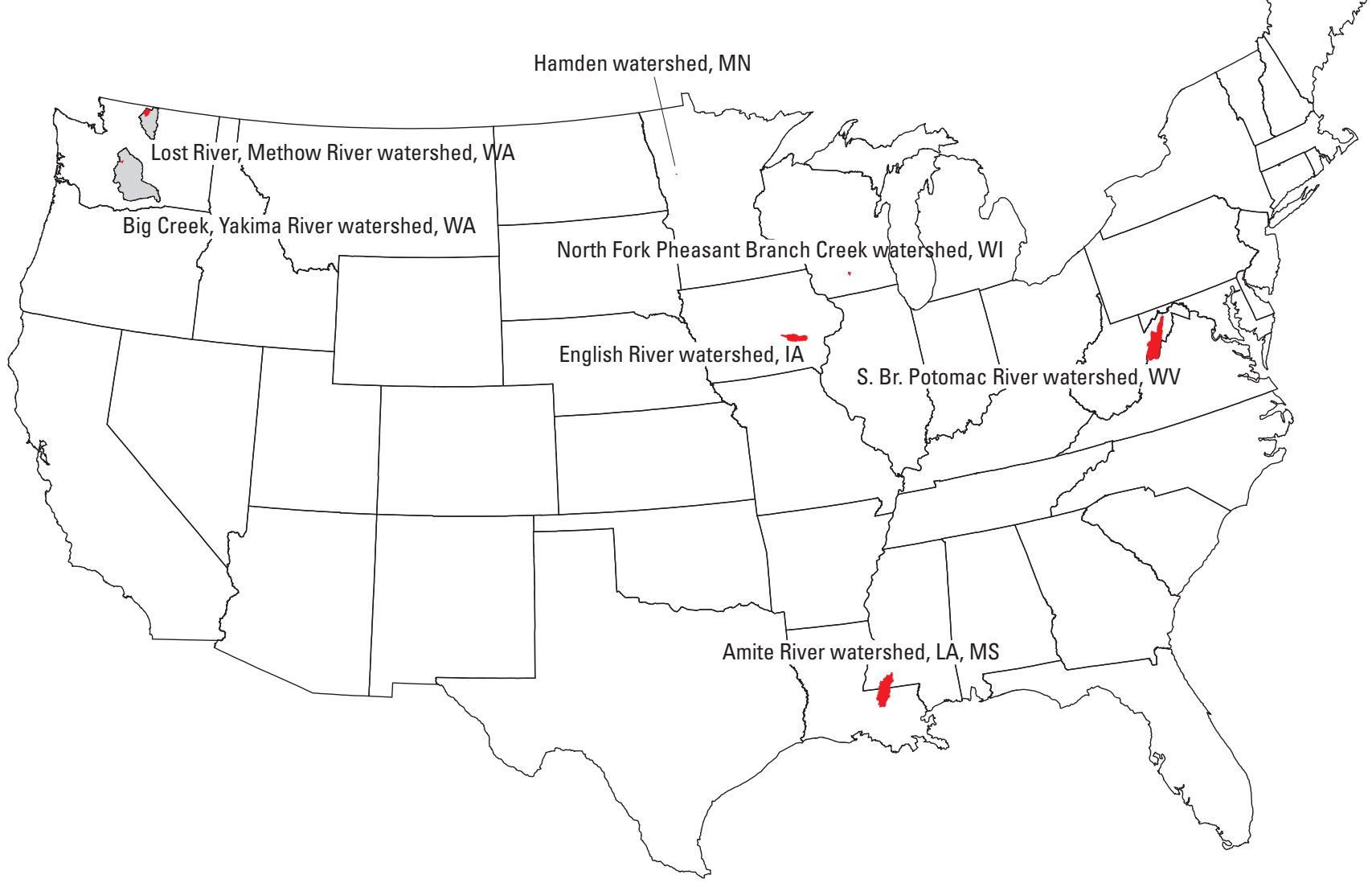

Figure 2. Locations of seven watersheds examined for sensitivity of simulated ground-water recharge.

Table 1. Summary of watershed characteristics and simulation periods for seven watershed models.

\begin{tabular}{|c|c|c|c|c|c|c|}
\hline \multirow[t]{2}{*}{ Watershed name } & \multirow{2}{*}{$\begin{array}{l}\text { Watershed } \\
\text { area } \\
\text { (square miles) }\end{array}$} & \multirow{2}{*}{$\begin{array}{l}\text { Mean } \\
\text { altitude } \\
\text { (feet) }\end{array}$} & \multirow{2}{*}{$\begin{array}{c}\text { Simulated } \\
\text { recharge } \\
\text { (inches per } \\
\text { year) }\end{array}$} & \multirow{2}{*}{$\begin{array}{c}\text { Simulated } \\
\text { precipitation } \\
\text { (inches per year) }\end{array}$} & \multicolumn{2}{|c|}{$\begin{array}{c}\text { Simulated mean } \\
\text { temperature } \\
\text { (degrees Fahrenheit) }\end{array}$} \\
\hline & & & & & Minimum & Maximum \\
\hline \multicolumn{7}{|l|}{ Simulation period 10-01-94 to 09-30-97 } \\
\hline Amite River, Louisiana and Mississippi & 1,335 & 243 & 15.2 & 61.9 & 53.5 & 75.5 \\
\hline \multicolumn{7}{|l|}{ Simulation period 10-01-95 to 09-30-98 } \\
\hline Lost River, Methow River Watershed, Washington & 167 & 5,940 & 6.4 & 54.7 & 26.3 & 41.4 \\
\hline Big Creek, Yakima River Watershed, Washington & 27 & 4,180 & 14.4 & 75.3 & 36.2 & 49.3 \\
\hline North Fork Pheasant Branch Creek, Wisconsin & 18 & 1,053 & 6.4 & 33.4 & 35.1 & 53.7 \\
\hline English River, Iowa & 581 & 837 & 10.4 & 36.5 & 38.4 & 57.7 \\
\hline South Branch Potomac River, West Virginia & 1,471 & 2,182 & 23.7 & 37.6 & 41.3 & 66.8 \\
\hline \multicolumn{7}{|l|}{ Simulation period 04-01-99 to 09-30-02 } \\
\hline Hamden Watershed, Minnesota & 10 & 1,283 & 0.1 & 28.6 & 34.1 & 56.4 \\
\hline
\end{tabular}




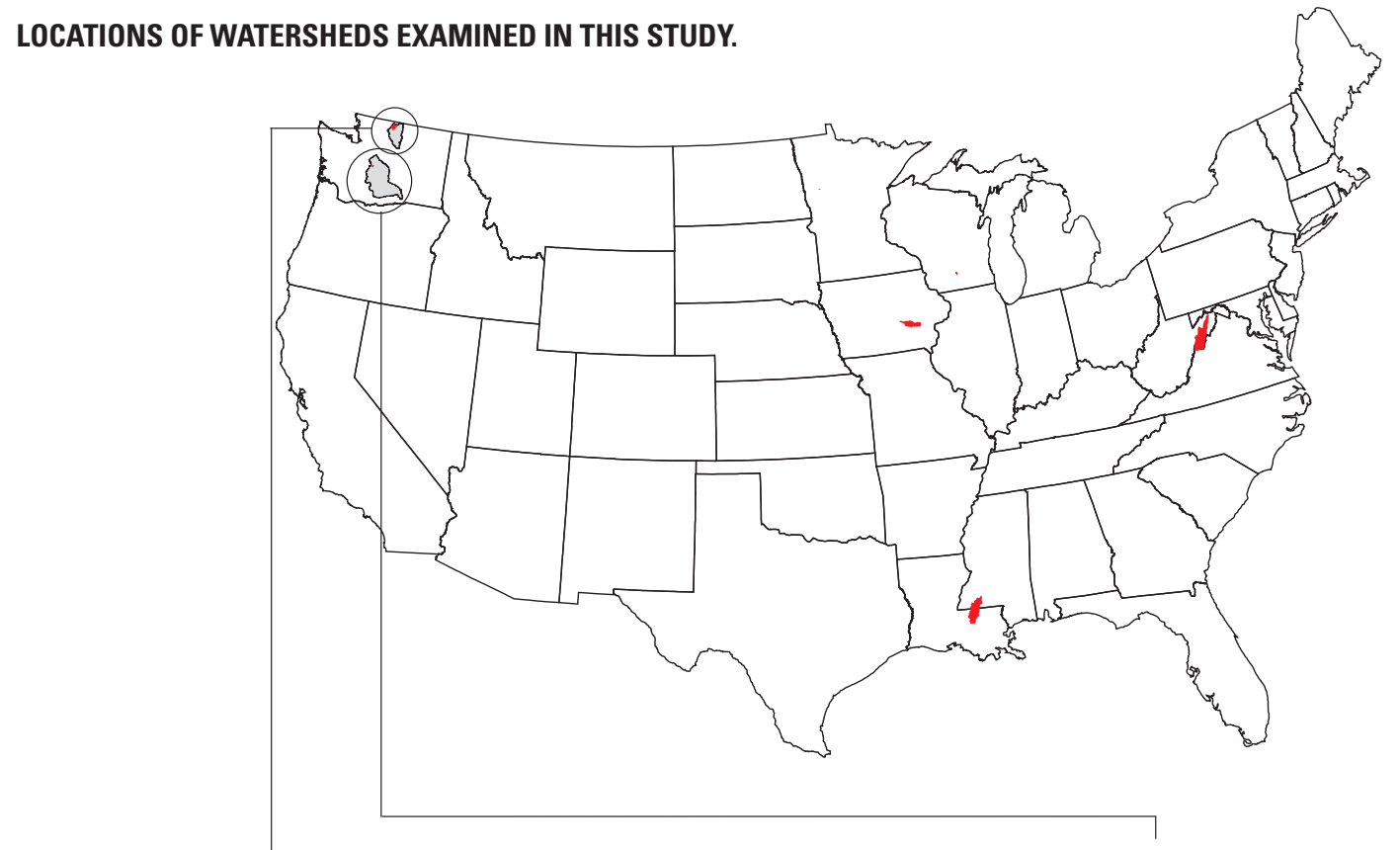

LOST RIVER, METHOW RIVER WATERSHED, WA

BIG CREEK, YAKIMA RIVER WATERSHED, WA
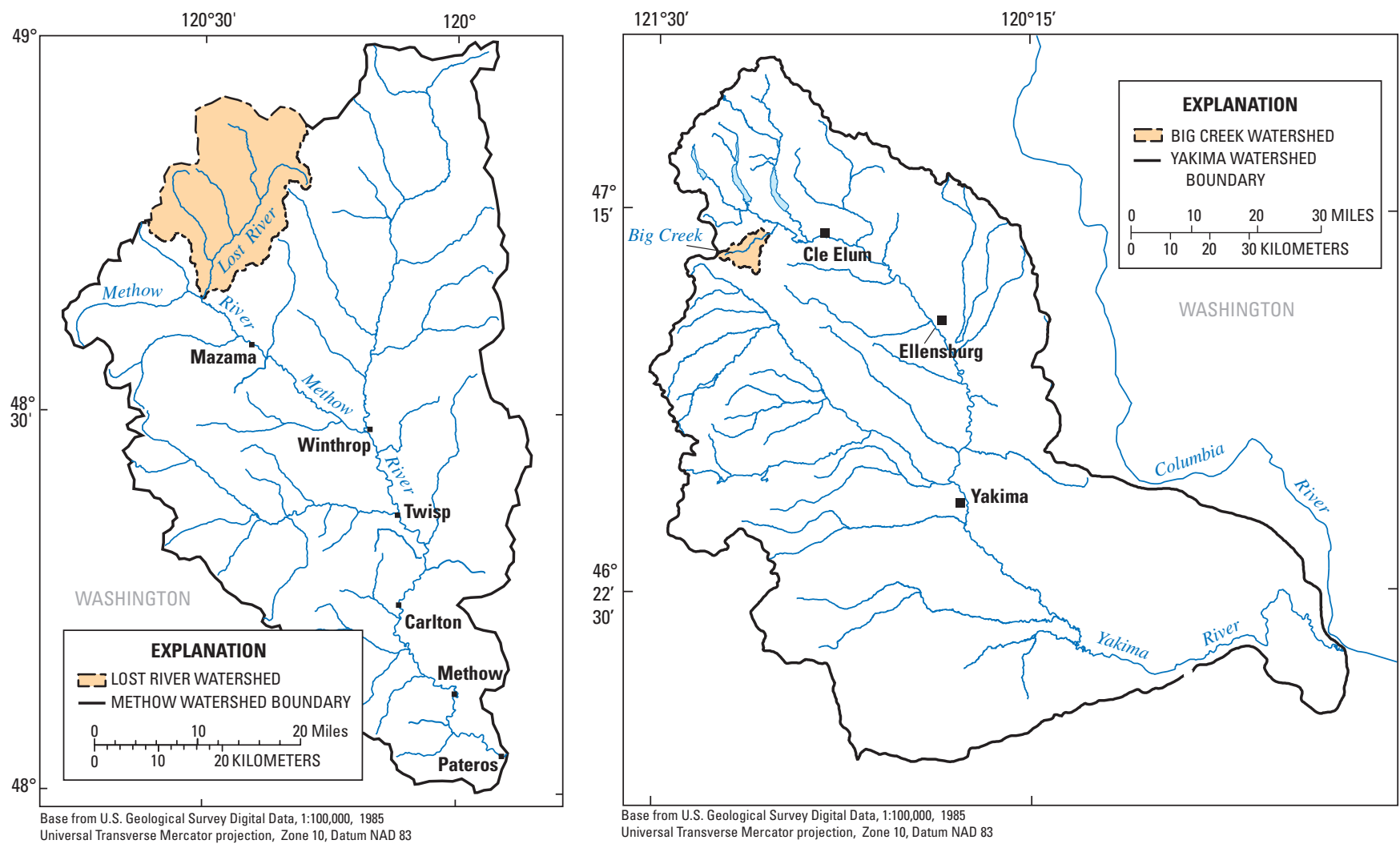

Figure 3. Locations of Lost River, Methow River watershed (from Ely, 2003) and Big Creek, Yakima River watershed, Washington (from Mastin and Vaccaro, 2002) 


\section{Big Creek, Yakima River Watershed, Washington}

Big Creek is a small watershed in the northwestern part of the Yakima River watershed in south-central Washington State, and covers an area of $27 \mathrm{mi}^{2}$ (fig. 3, table 1). Big Creek originates on the humid east slope of the Cascade Range, where watershed average precipitation for the simulation period, as computed by the model, was about 75 in/yr. The Big Creek watershed ranges from peaks reaching 4,600 ft above sea level along the Cascade crest down to 2,080 ft at the confluence with the Yakima River. Simulated annual mean streamflow was $90 \mathrm{ft}^{3} / \mathrm{s}$.

Big Creek watershed was simulated as part of the Yakima River Watershed Decision Support System (Mastin and Vaccaro, 2002). The purpose of the model was to provide a tool for improving water management in the watershed. Mean annual streamflow for Big Creek, an ungaged tributary, was estimated by regression equations and calibrated to available snowpack and streamflow data.

\section{Hamden Watershed, Minnesota}

The Hamden watershed site is in west-central Minnesota (fig. 4). The watershed covers $10 \mathrm{mi}^{2}$ (table 1) in rolling terrain, ranging from 1,420 ft above sea level in the east to $1,230 \mathrm{ft}$ above sea level in the west. Annual precipitation is about 29 in/yr. Many marshes, wetlands, and well-defined drainage channels are at the site.

The Hamden watershed model was developed to investigate the runoff-process relations with wetlands and other landscape features (K.C. Vining, U.S. Geological Survey, written commun., 2003). PRMS modules were designed specifically for routing water to wetland features. After user-defined soil-moisture conditions were met, the remaining water was routed to the ground-water reservoir, stream channel, and wetlands. The model was calibrated for streamflow by adjusting the values and coefficients for soilwater-holding capacity, open wetlands spillage thresholds, and area contribution to streamflow. The addition of wetland storage limited the volume of water routed to the ground-water reservoir.

\section{North Fork Pheasant Branch Creek Watershed, Wisconsin}

The North Fork Pheasant Branch Creek watershed, in south-central Wisconsin, comprises the South Fork and North Fork watersheds and a lower system that flows into a marsh. The overall watershed covers an area of $18 \mathrm{mi}^{2}$ (fig. 4, table 1). Average annual precipitation during 1995-98 was 33 in/yr. Annual mean streamflow for the Pheasant Branch at U.S. Highway 12, near Middleton, Wis. (USGS streamflow-gaging station 05427948) during 1974-99 was $4.6 \mathrm{ft}^{3} / \mathrm{s}$. The watershed consists of gently rolling upland hills, heavily cultivated fields in the flood plains, and large areas of development (Steuer and Hunt, 2001).

A model with an emphasis on the North Fork Pheasant Branch Creek watershed was developed to provide a scientific basis for evaluating changes to the water resources (Steuer and Hunt, 2001). All components of the hydrologic system were quantified, and output from the watershed simulation (recharge) was coupled with a ground-water flow model. The watershed simulation was initially calibrated by trial-and-error adjustments of parameters relating to the annual water balance. Published potential evapotranspiration values, measured infiltration rates, and daily and annual runoff constrained the final calibration.

\section{MOPEX Watersheds}

The international Model Parameter Estimation Experiment (MOPEX) is an ongoing effort adopted as projects of the International Association of Hydrological Sciences and the World Meteorological Organization. The goal of MOPEX is to develop techniques for the a priori estimation of parameters used in atmospheric and hydrologic models. Benchmark watersheds were modeled to create a database of watersheds for future study. The purpose and scope of MOPEX watershed models are considerably different from the other models used in this analysis. MOPEX evolved to address the parameter uncertainty of ungaged watersheds and assess new techniques to decrease the uncertainty.

Three of the humid-region benchmark watersheds were selected for use in the parameter-sensitivity study: Amite River near Denham Springs, Louisiana; English River at Kalona, Iowa; and South Branch Potomac River near Springfield, West Virginia (G. Leavesley, U.S. Geological Survey, written commun., 2004) (fig. 5). The first step to the MOPEX calibration strategy was to make control runs using existing data sets for the watershed climate, soils, vegetation, and topographic features. The second step was to calibrate the model to existing streamflow data and develop relationships between the parameter values and the input data sets.

The Amite River watershed is in southeastern Mississippi and eastern Louisiana. The watershed covers $1,335 \mathrm{mi}^{2}$ (table 1). Mean altitude of the watershed is $243 \mathrm{ft}$ above sea level and minimum altitude is $0 \mathrm{ft}$. Amite River watershed average precipitation computed by the model was about 62 in/yr. Annual mean streamflow for the Amite River near Denham Springs, La. (USGS streamflow-gaging station 07378500) during 1939-2001 was $2,120 \mathrm{ft}^{3} / \mathrm{s}$.

The English River watershed is in southeastern Iowa. The watershed covers $581 \mathrm{mi}^{2}$ (table 1). Mean altitude of the watershed is $837 \mathrm{ft}$ above sea level, with a minimum elevation of $633 \mathrm{ft}$ above sea level. Watershed average precipitation computed by the model was about 36 in/yr. Annual mean streamflow for the English River at Kalona, Iowa (USGS streamflow-gaging station 05455500) during 1940-2003 was $390 \mathrm{ft}^{3} / \mathrm{s}$. 


\section{LOCATION OF WATERSHEDS EXAMINED IN THIS STUDY.}

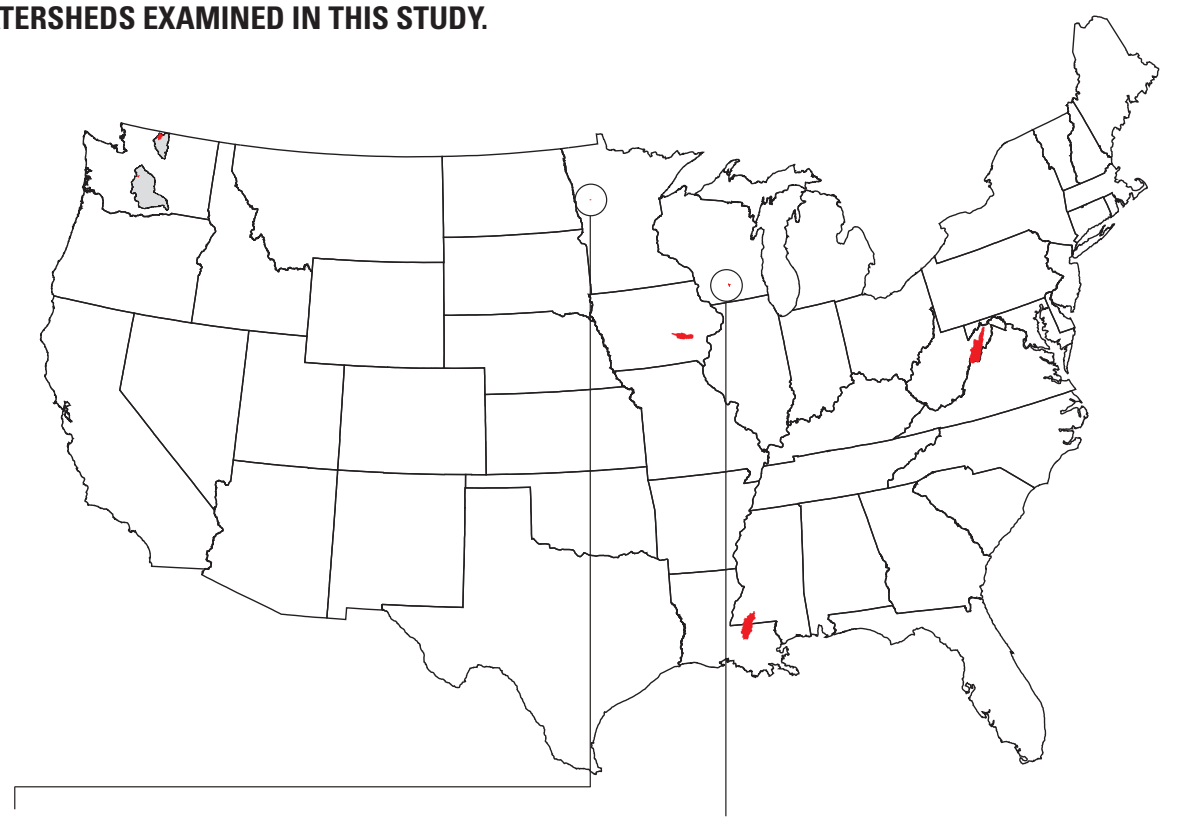

\section{HAMDEN WATERSHED, MN}

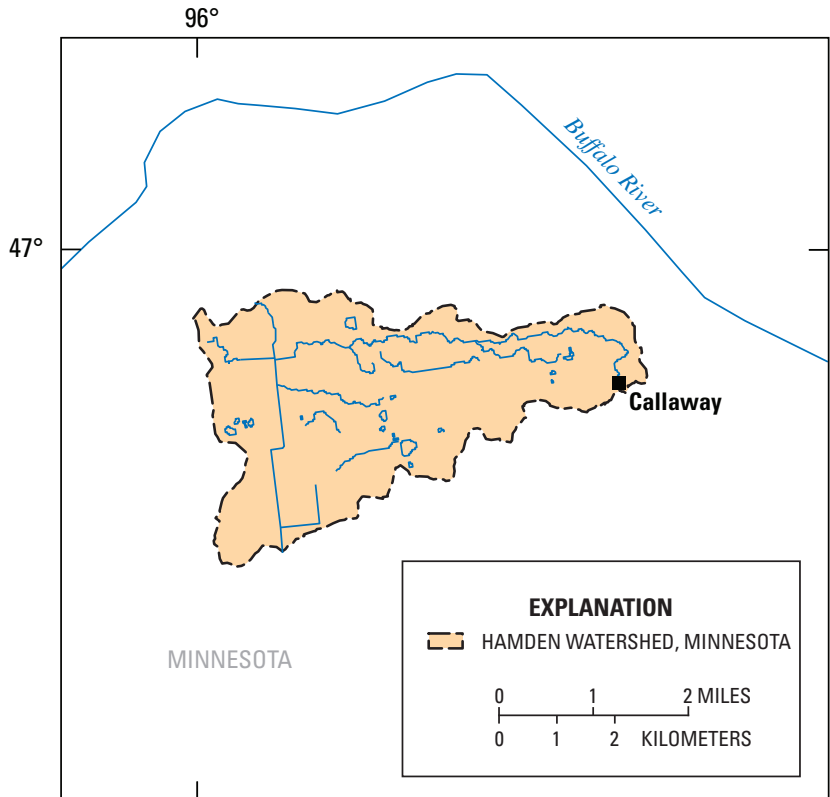

Base from U S. Geological Survey Digital Data, 1:100,000, 1985 Universal Transverse Mercator projection, Zone 15, Datum NAD 83
NORTH FORK PHEASANT BRANCH CREEK WATERSHED, WI

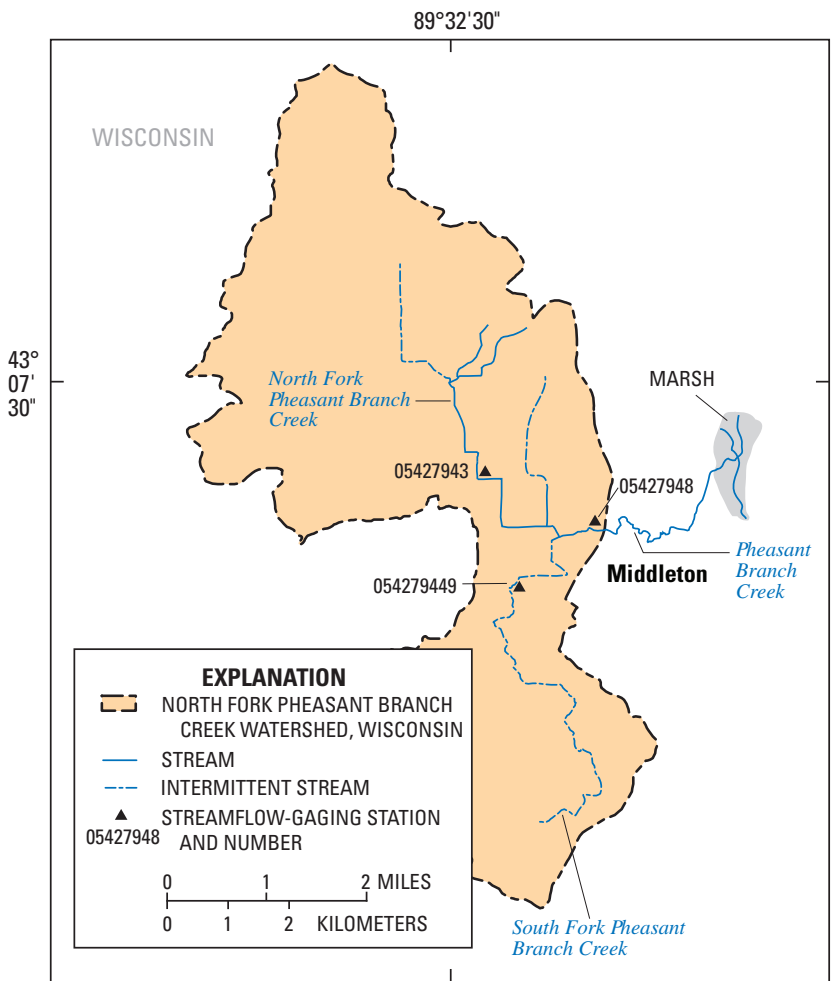

Base from U.S. Geological Survey Digital Data, 1:100,000, 1985 Universal Transverse Mercator projection, Zone 15, Datum NAD 83

Figure 4. Locations of Hamden watershed, Minnesota (K.C. Vining, U.S. Geological Survey, written commun., 2003) and North Fork Pheasant Branch Creek watershed near Middleton, Wisconsin (from Steuer and Hunt, 2001). 
LOCATIONS OF WATERSHEDS EXAMINED IN THIS STUDY.

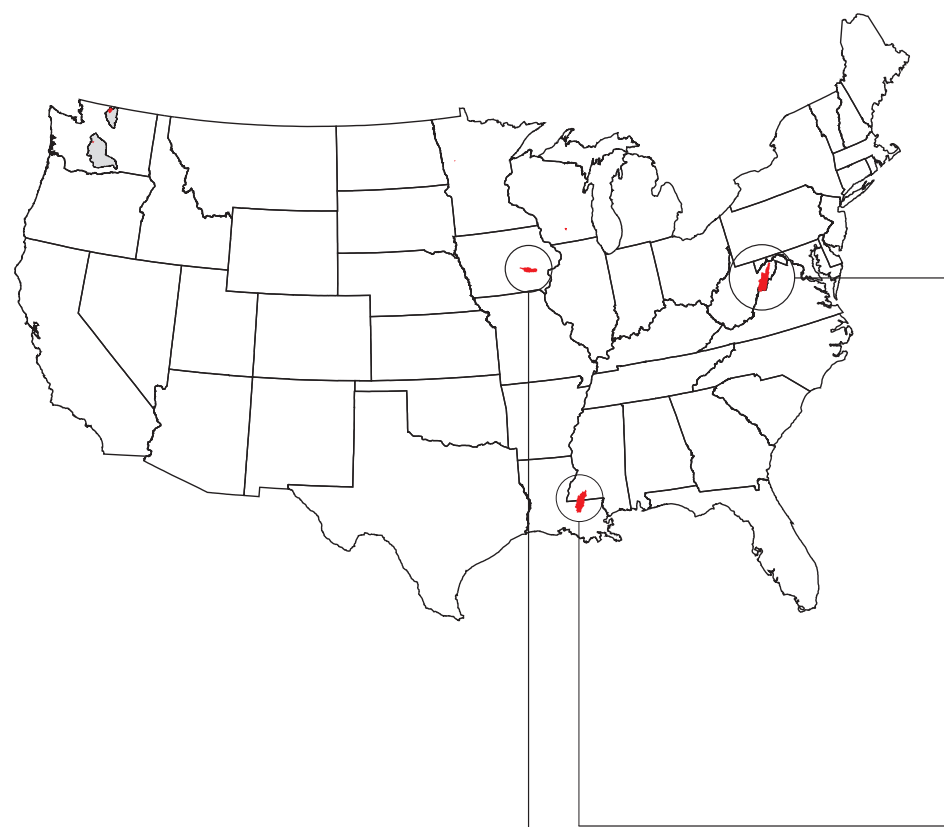

SOUTH BRANCH POTOMAC RIVER WATERSHED, WV

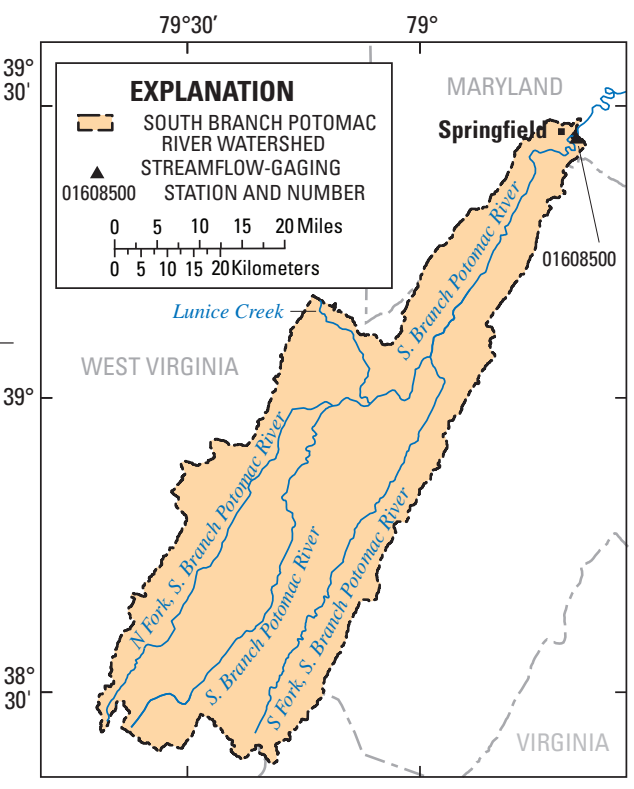

Base from U.S. Geological Survey Digital Data, 1:100,000, 1985 Universal Transverse Mercator projection, Zone 17, Datum NAD 83
ENGLISH RIVER WATERSHED AT KALONA, IA

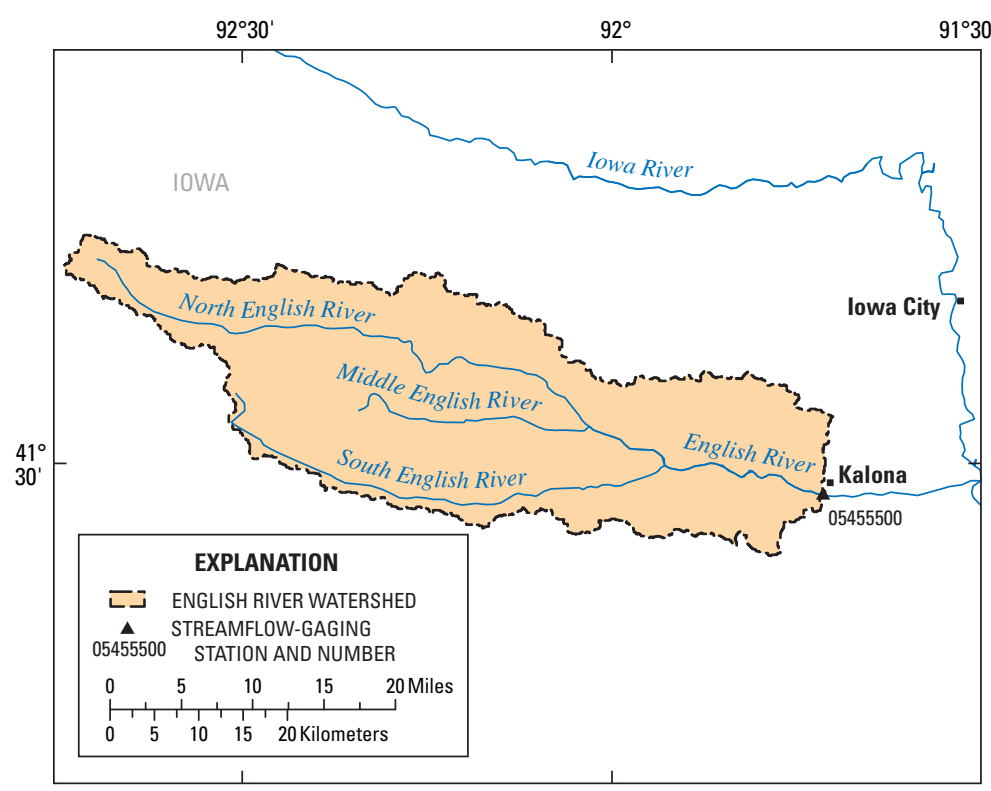

Base from U.S. Geological Survey Digital Data, 1:100,000, 1985

Universal Transverse Mercator projection, Zone 15, Datum NAD 83
AMITE RIVER WATERSHED, LA AND MS

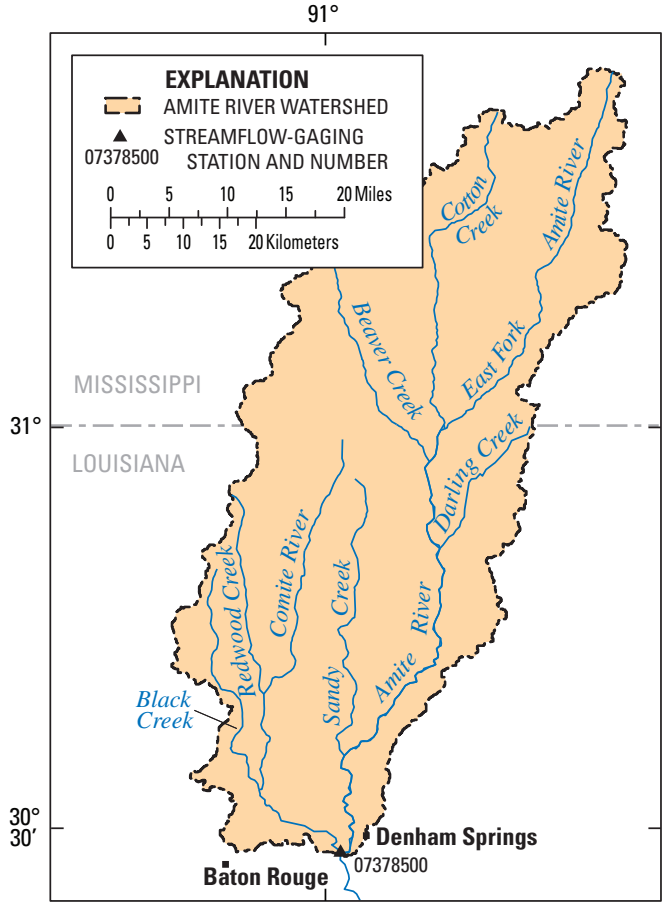

Base from U.S. Geological Survey Digital Data, 1:100,000, 1985 Universal Transverse Mercator projection, Zone 15, Datum NAD 83

Figure 5. Locations of the Amite River watershed, Louisiana and Mississippi; English River watershed, lowa; and South Branch Potomac River watershed, West Virginia. 
The South Branch Potomac River watershed is in northeastern West Virginia. The watershed covers 1,471 $\mathrm{mi}^{2}$ (table 1). Mean altitude of the watershed is $2,182 \mathrm{ft}$ above sea level, with a minimum altitude of $560 \mathrm{ft}$ above sea level. Watershed average precipitation computed by the model was about 38 in/yr. Annual mean streamflow for the South Branch Potomac River near Springfield, W. Va. (USGS streamflowgaging station 01608500) during 1900-2002 was 1,340 ft $3 / \mathrm{s}$.

\section{Sensitivity Analysis}

The nonlinear regression model UCODE (Poeter and Hill, 1998) was used to analyze the sensitivity of recharge to parameters for the seven existing watershed models. No attempt was made to recalibrate the models or to evaluate the statistical measures of model fit. The diagnostic statistics generated by UCODE were used to measure the amount of information provided by the data.

\section{Statistics Description}

UCODE is a computer program that uses nonlinear regression to minimize a weighted least-squares objective function with respect to the parameter values using a modified Gauss-Newton method. UCODE is a universal inverse model that can be applied to any model, making it powerful and versatile. UCODE also can use standard linear methods to generate diagnostic statistics that measure the amount of information provided by the data. Two statistics of greatest utility in this study were dimensionless scaled sensitivities (DSS) and composite scaled sensitivities (CSS). A complete discussion of these statistics is given in Hill (1998) and Poeter and Hill (1998).

Dimensionless scaled sensitivities indicate the importance of an observation (here, the daily mean recharge) to the estimation of a parameter or, conversely, the sensitivity of the simulated equivalent of the observation to the parameter.

Composite scaled sensitivities indicate the information content of all the observations for the estimation of a parameter.

Poeter and Hill (1998) explained that one sensitivity equals the derivative of a simulated value with respect to one parameter. The dimensionless scaled sensitivity, $d s s_{i j}$, is calculated as (Hill, 1998):

$$
d s s_{i j}=\left(\frac{\partial y_{i}^{\prime}}{\partial b_{j}}\right) b_{j} \omega_{i}^{1 / 2}
$$

where

$i$ identifies one of the observations,

$j$ identifies one of the parameters,

$y^{\prime}{ }_{i}$ is the simulated value associated with the $i t h$

observation,

$b_{j}$ is the $j$ th estimated parameter,

$\partial y_{i}^{\prime}$ is the sensitivity of the simulated value associated

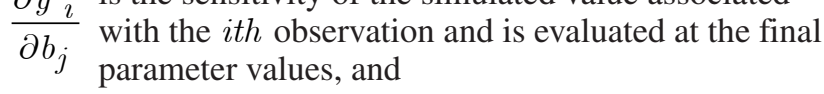

$\omega_{i}$ is the weight for the $i t h$ observation.

CSS summarize all the sensitivities for one parameter. CSS are calculated for each parameter using the dimensionless scaled sensitivities for all observations. Because they are dimensionless, CSS can be used to compare the amount of information provided by different types of parameters. Model simulation results will be more sensitive to parameters with large CSS relative to those for other parameters. The CSS for the $j$ th parameter, $c s s_{j}$, is calculated as (Hill, 1998):

$$
c s s_{j}=\left[\frac{\left.\sum_{i=1}^{N D}\left(d s s_{i j}\right)^{2}\right|_{\underline{b}}}{N D}\right]^{\frac{1}{2}},
$$

where

$N D$ is the number of observations being used in the regression,

$\underline{b}$ is a vector that contains the parameter values at which the sensitivities are evaluated,

and the quantity in parenthesis equals the scaled sensitivities of equation 1 .

Parameter correlation coefficients indicate if two or more parameters can be uniquely estimated (optimized) by nonlinear regression. They are calculated as the covariance between two parameters, divided by the product of the standard deviation. Correlation coefficients range from -1.0 to 1.0 and absolute values larger than 0.95 may indicate a possible high degree of correlation. If extreme parameter correlation exists, the correlation coefficient will be close to 1.0 or -1.0 . A low degree of correlation implies that the action of one parameter is independent of the action of another parameter with regard to the value of the simulated output. The implications of non-unique parameter values are explained in Poeter and Hill (1997). 


\section{Analysis Process}

In this study, MMS was the application model executed by UCODE. UCODE manipulates the input parameter file of the existing watershed model and reads the simulated recharge values from the MMS output file. For the purposes of this study, "recharge" was defined as the area-weighted average of inflow to the ground-water reservoir. Other studies have defined the recharge rate as the flow from the ground-water reservoir to the outlet (Steuer and Hunt, 2001; Lee and Risley, 2002).

The significance of 17 parameters to ground-water recharge estimates (table 2) was analyzed for this study. Sixteen parameters were analyzed for all of the calibrated watershed models. An additional parameter defining the amount of snowpack that could infiltrate the soil (groundmelt) was analyzed for the Big Creek and Lost River watersheds, Washington. The additional groundmelt component supplies much of the water needed to support low flows when a watershed is snow-covered. Groundmelt is added to the upper part of the HRU soil zone.

Parameters were chosen that likely would have the greatest effect on recharge. From a physical point of view, those parameters that directly route water out of the subsurface reservoir, into the ground-water reservoir, or into streams, or that control ET should always be important because they directly affect the amount of water reaching the ground-water reservoir. Parameters that control the quantity of recharge as a function of soil and subsurface reservoir water storage volume should be considered important under most circumstances. Two other parameters determined the form of precipitation (rain versus snow) and the snow-covered area depletion curve.

Parameters directly responsible for the amount of precipitation were not included in the recharge-parameter analysis. The amount of precipitation, either as rain or as snow, was understood to have the greatest effect on recharge; therefore, those parameter sensitivities could overwhelm other sensitivities and mask subtler effects of the ground-water flow processes.

Scaled sensitivities were calculated by perturbing (increasing and decreasing) the final parameter values of the calibrated model and calculating the derivative of the simulated value (recharge), with respect to the parameter. The size of the perturbation is calculated as a user-specified factor. All parameters except tmax_allsnow were perturbed by 10 percent. Tmax_allsnow was perturbed by 1 percent, due to the relatively large parameter value ( 32 to $\left.35^{\circ} \mathrm{F}\right)$.

One limitation of this method is that integer values representing a soil type ( $1=$ sand, $2=$ loam, $3=$ clay $)$ or land cover type $(0=$ bare soil, $1=$ grasses, $2=$ shrubs, $3=$ trees $)$ could not be evaluated directly. Parameters associated with tree-cover density and soil properties were used as proxies.

Table 2. Description of Precipitation-Runoff Modeling System parameters used in sensitivity analysis for the seven watershed models.

[Abbreviations: ET, evapotranspiration; HRU, Hydrologic Response Unit]

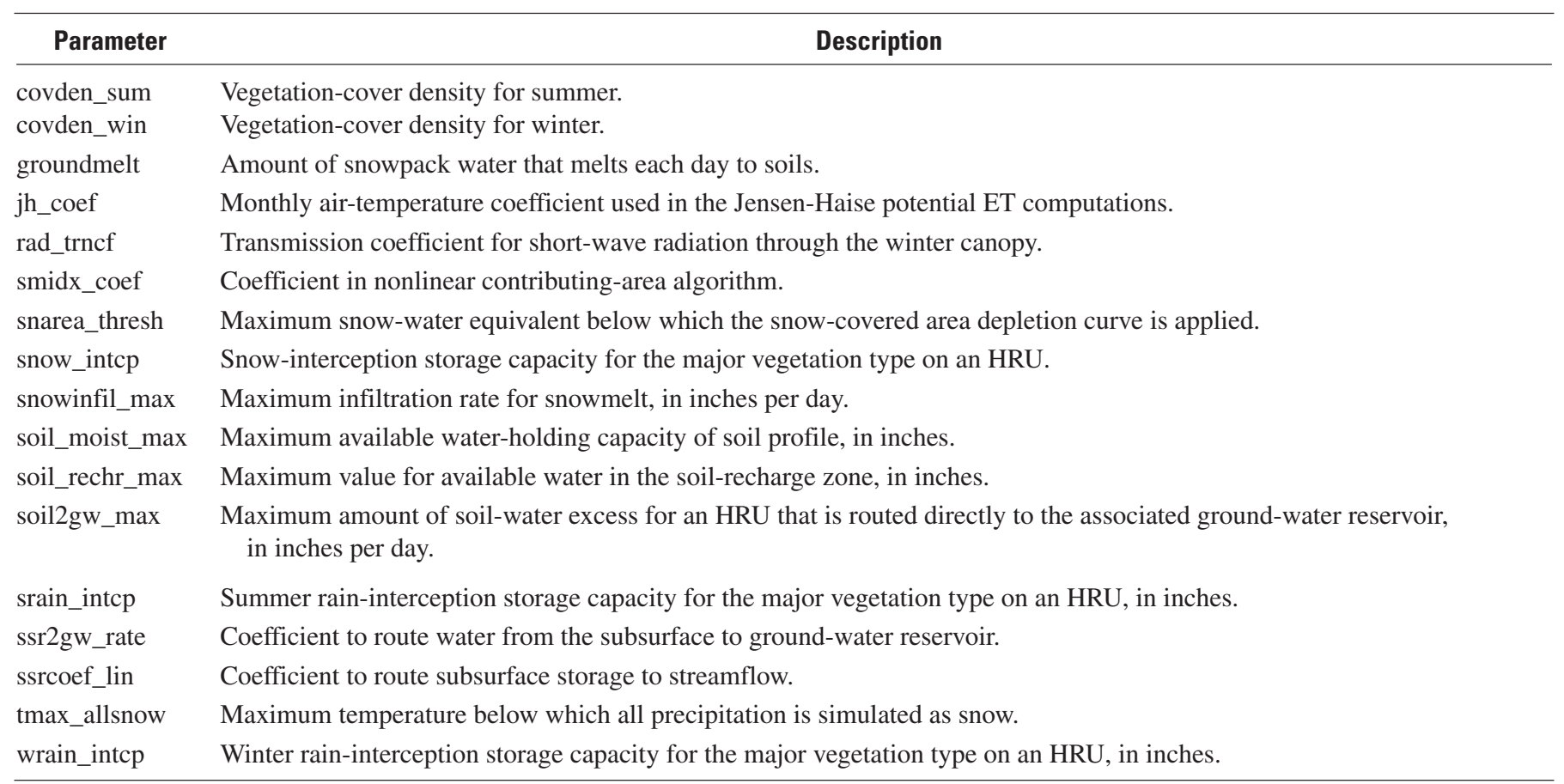




\section{Results of Sensitivity Analysis}

DSS for the five most significant parameters in each watershed were used to present the results of the sensitivity analyses (fig. 6). The CSS of all parameters were normalized by dividing their final values by the maximum CSS (figs. 710). No parameter correlation coefficient for any of the seven watershed models indicated an inability to uniquely estimate a parameter value (absolute value greater than 0.95) (table 3).

The Lost River and Big Creek watersheds, Washington, are similar; both are high-altitude, mountainous watersheds with an average precipitation exceeding $50 \mathrm{in} / \mathrm{yr}$ and the coldest temperatures of the seven watersheds. Much of the precipitation is snow, and the spring snowmelt produces the peak streamflow. The greatest CSS in both watersheds was tmax_allsnow (maximum temperature below which all precipitation is simulated as snow), as much as five times greater than the next greatest CSS (ig. 7). Tmax_allsnow controls the amount of excess water available in the soil that then can be routed directly to ground water or to the subsurface and then the ground water. It can affect recharge volume by affecting actual evapotranspiration (AET) (for example, the more snowmelt, the longer soils can be saturated). This effect could be insignificant if the snowmelt occurs during periods of low AET.

Tmax_allsnow determines whether the precipitation falls as snow or rain, and therefore affects the timing of recharge more than it does the total volume. The importance of tmax_allsnow is related to the number of days the simulated maximum daily temperature ranges between 30 and $35^{\circ} \mathrm{F}$. Those days are represented by the spikes in the graphs of DSS (fig. $6 \mathrm{~A}, \mathrm{~B}$ ). A change of $0.3^{\circ} \mathrm{F}$ in the simulated maximum daily temperature would affect the form of precipitation (rain or snow) on 20 days in the Lost River watershed and 25 days in the Big Creek watershed over the 3-year simulation period. The sensitivity of recharge to this parameter also indicates the susceptibility of these watersheds to minor climate change. As with streamflow, much of the ground-water recharge originates as snowmelt.

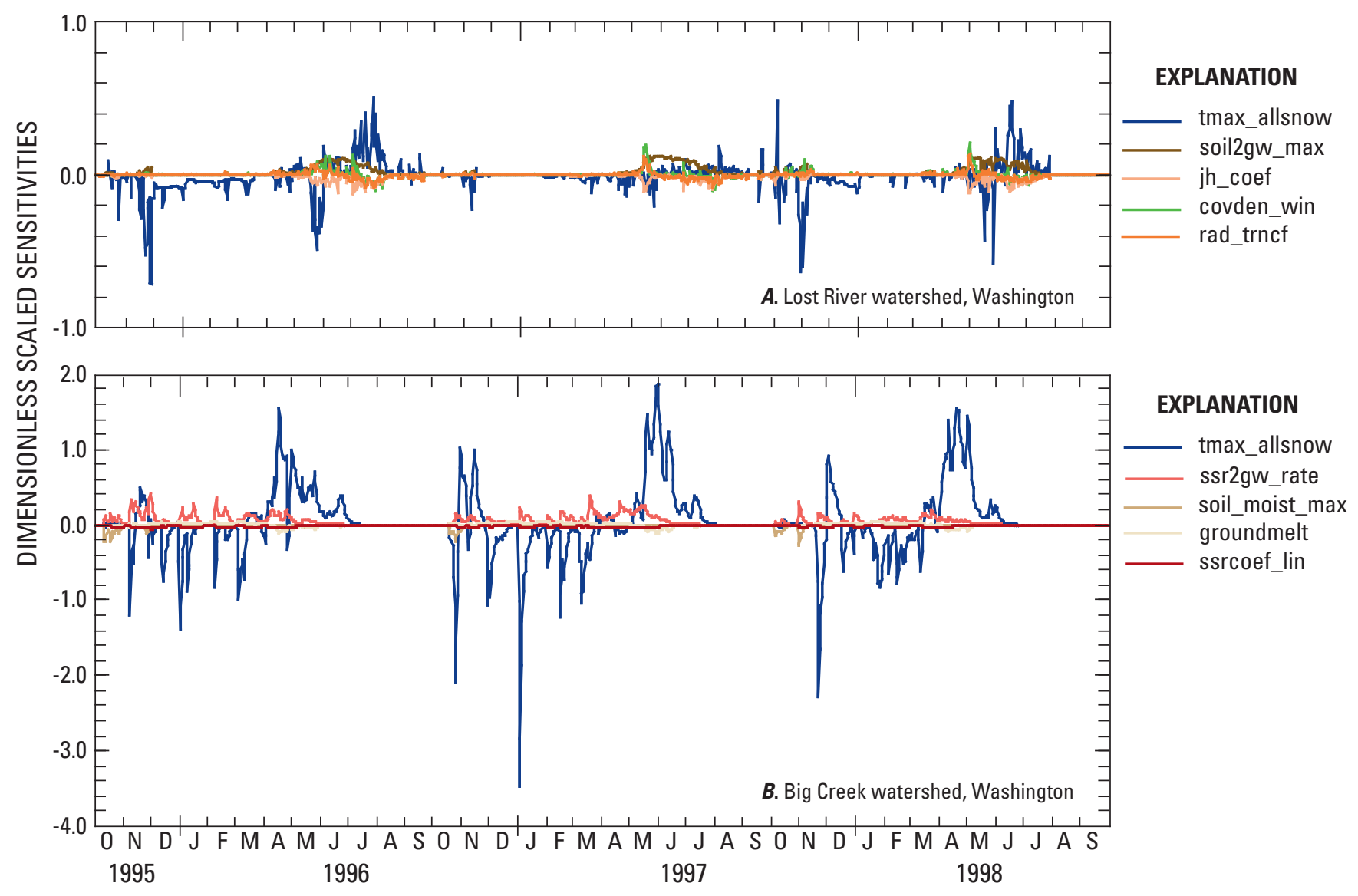

Figure 6. Dimensionless scaled sensitivities of the five most significant model parameters, in descending order, for seven watershed models. 


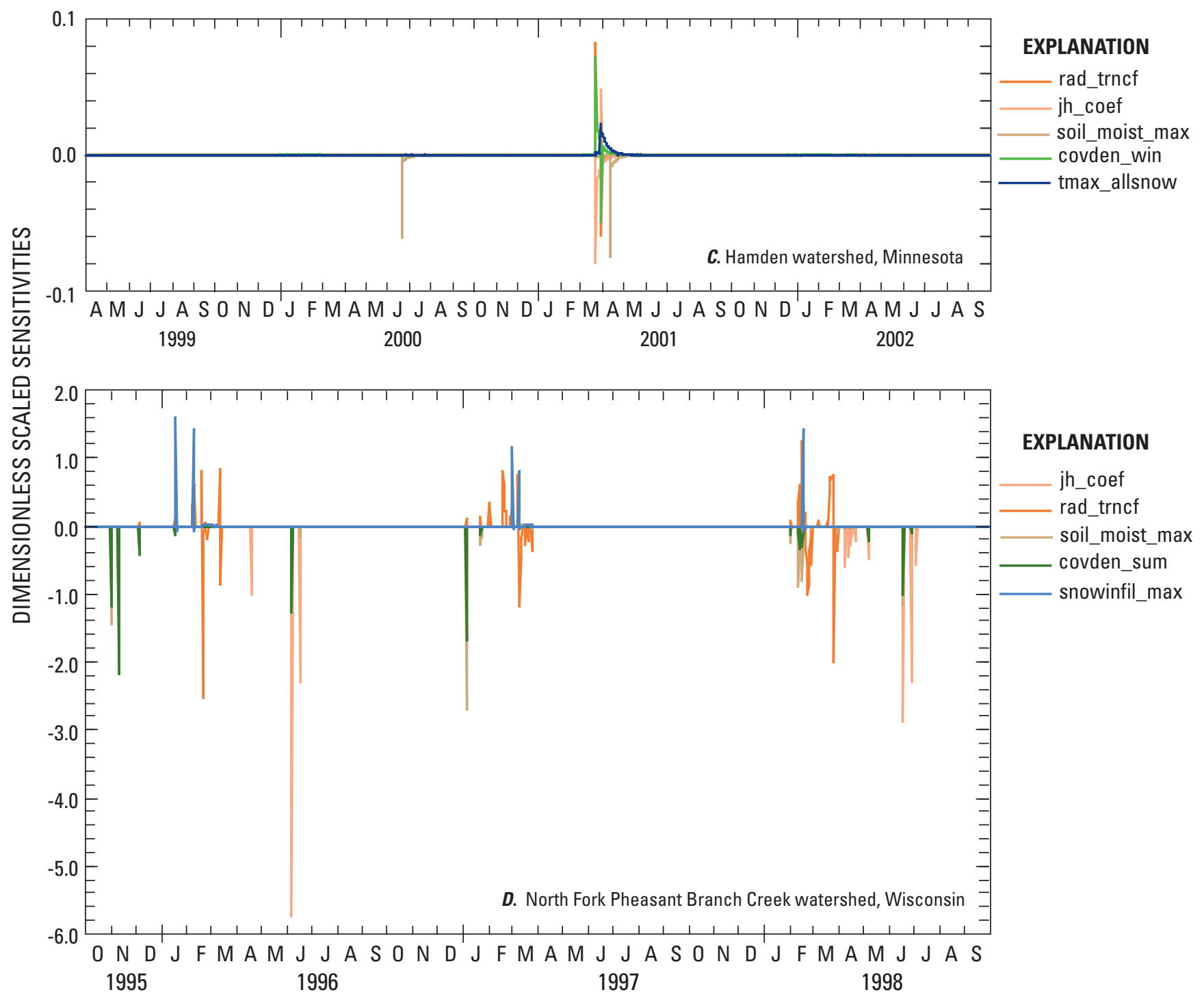

Figure 6.-Continued.

The second most important parameters for the Lost River and Big Creek watersheds are both "routing" parameters. Recharge in Lost River watershed is sensitive to soil2gw_max, the maximum amount of soil-water excess routed directly to the associated ground-water reservoir. Recharge in Big Creek watershed is sensitive to ssr2gw_rate. This parameter is a coefficient to route water from the subsurface to the ground-water reservoir. The importance of two different parameters that both route water to the ground-water reservoir in similar watersheds could indicate a difference in the focus of calibration. The modeler could preferentially route water to the ground-water reservoir from one source over another, increasing the sensitivity.
The calibration approach can affect any parameter that sets a maximum amount of flow. If the parameter value is set unrealistically high, or if the simulated value never approaches the maximum value, the parameter will appear to be insensitive. For example, if soil_moist_max (maximum available water-holding capacity of the soil profile) is set to 6 in., but the simulated water in the soil profile only reaches 2 in., the simulation will be insensitive to small perturbations of the parameter value. However, if that same parameter value is set to 1.5 in., the simulation will be very sensitive as it routes the excess soil moisture to a different reservoir. 


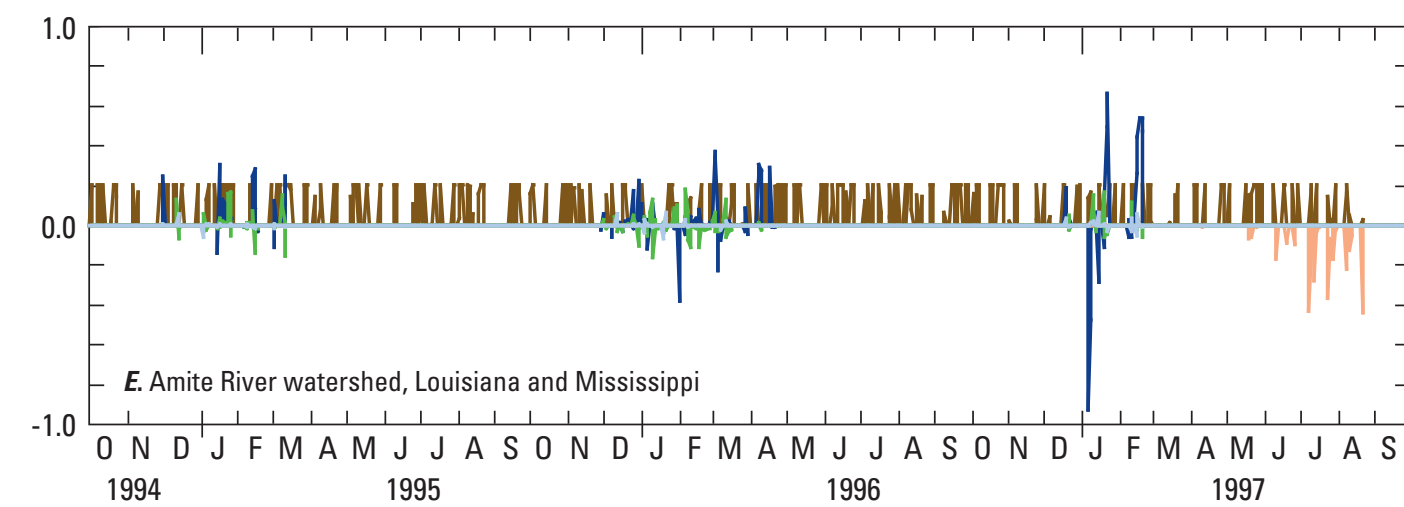

EXPLANATION

- soil2gw_max

tmax_allsnow

- jh_coef

covden_win snow_intcp

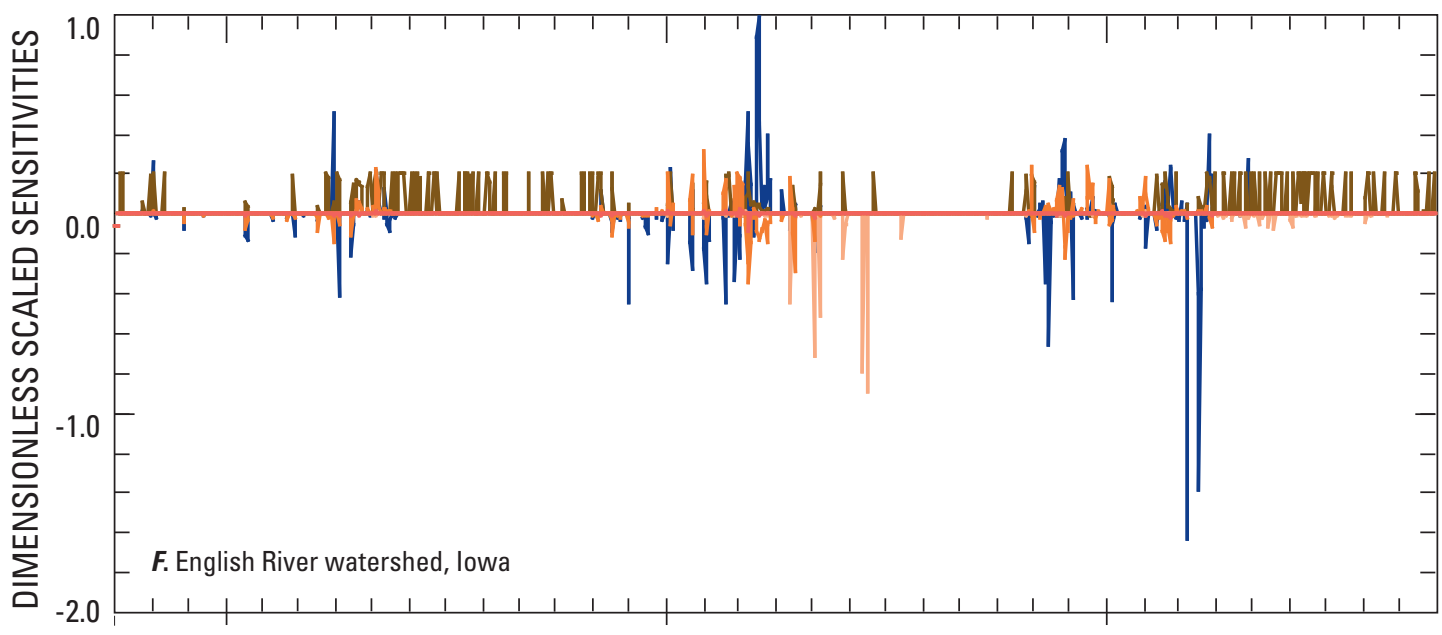

EXPLANATION

_ tmax_allsnow

— soil2gw_max

- jh_coef

rad_trncf

ssr2gw_rate

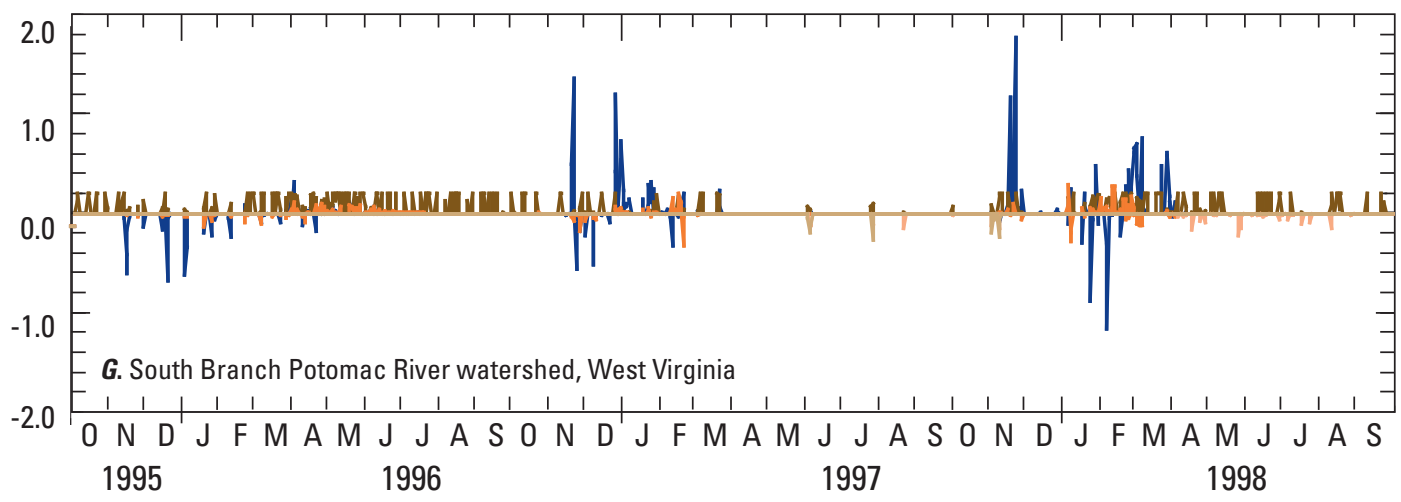

EXPLANATION

tmax_allsnow

soil2gw_max

rad_trncf

jh_coef

soil_moist_max

Figure 6.-Continued. 
Table 3. Parameter correlation coefficients greater than 0.85 or less than -0.85 for seven watershed models.

[See table 2 for parameter definitions]

\begin{tabular}{llr}
\hline \multicolumn{1}{c}{ Watershed name } & Parameter / Parameter & $\begin{array}{c}\text { Correlation } \\
\text { coefficient }\end{array}$ \\
\hline Lost River, Methow River Watershed, Washington & $\left({ }^{1}\right)$ & \\
Big Creek, Yakima River Watershed, Washington & smidx_coef / soil_moist_max & -0.94 \\
& snow_intcp / wrain_intcp & .94 \\
North Fork Pheasant Branch Creek, Wisconsin & ssr2gw_rate / ssrcoef_lin & .90 \\
Amite River, Louisiana and Mississippi & covden_sum / srain_intcp & -.90 \\
English River, Iowa & smidx_coef / soil_moist_max & -.92 \\
South Branch Potomac River, West Virginia & $\left({ }^{1}\right)$ & \\
Hamden Watershed, Minnesota & $\left({ }^{1}\right)$ & \\
\hline
\end{tabular}

${ }^{1}$ None greater than 0.85 or less than -0.85 .

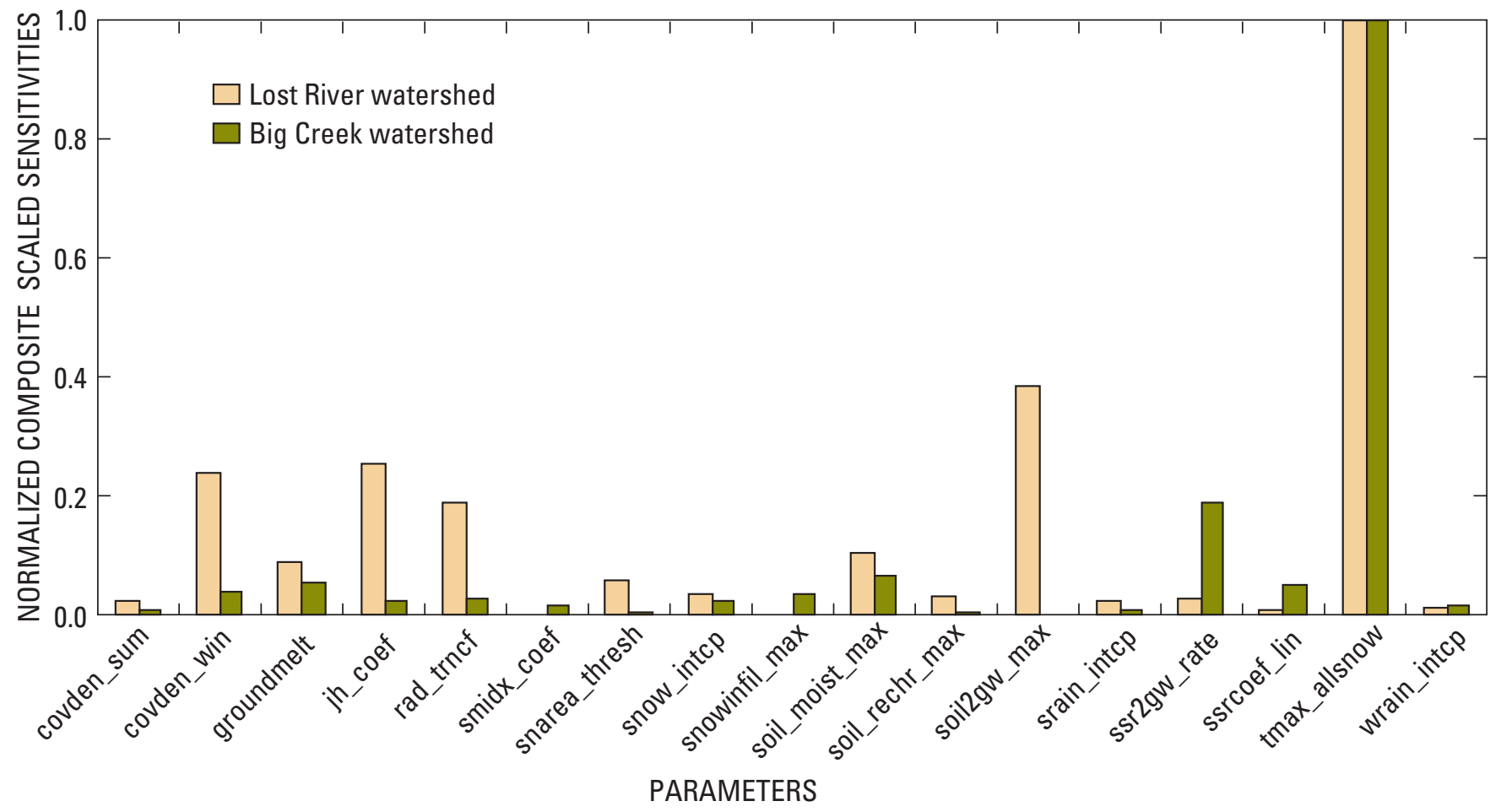

Figure 7. Normalized composite scaled sensitivities of model parameters for the Lost River and Big Creek watersheds, Washington. 
All DSS for the Hamden watershed in Minnesota were low (fig. 6C). Most of the water satisfied soil moisture conditions and the remainder flowed to the stream channel and wetlands. Simulated flow to the ground-water reservoir was greater than $0.005 \mathrm{in} / \mathrm{d}$ only twice, 1 week in June 2000 and 1 month in spring 2001. For these two periods, recharge was sensitive to the parameters that control AET (covden_win, jh_coef, rad_trncf, and soil_moist_max,) (fig. 8).

The North Fork Pheasant Branch watershed simulation shows various important parameters suggesting no single dominant process. Steuer and Hunt (2001) report that much of the recharge at the North Fork Pheasant Branch watershed, Wisconsin, occurs during winter and spring, when snow is melting, or during autumn, when ET is reduced. The high recharge parameter sensitivities for jh_coef (monthly air-temperature coefficient used in the Jensen-Haise potential ET computations), rad_trncf (transmission coefficient for short-wave radiation through the winter canopy), and covden_sum (vegetation-cover density for summer) indicate the importance of ET in limiting the summer recharge and allowing the autumn and winter recharge (figs. $6 D$ and 9 ). Maximum air temperature is between 30 and $35^{\circ} \mathrm{F}$ many days each year in the North Fork Pheasant Branch watershed, but less precipitation falls during this time; therefore, tmax_allsnow is ranked as only the sixth most important parameter to recharge.
Parameter sensitivities for the three MOPEX watersheds were remarkably similar. Recharge in the Amite River, English River and South Branch Potomac River watersheds was highly sensitive to tmax_allsnow and soil2gw_max. Jh_coef was ranked third for two of the watershed simulations and fourth for the other simulation (figs. $6 E-G$ ). Tmax_allsnow and jh_coef are sensitive only during specific episodes indicating unique conditions resulted in the recharge being sensitive to the parameters. DSS for tmax_allsnow spiked for short periods, typically 1 day to 1 week, when precipitation fell and temperatures were near $35^{\circ} \mathrm{F}$ in the MOPEX watershed simulations.

More interesting is the similarity of the CSS and DSS for soil2gw_max (figs. $6 E-G$ and fig. 10). The rather continuous high sensitivity of soil2gw_max indicates that soil saturation has dominant control over recharge through most of the year. On 18 percent of the days in the Amite River simulation and 11 percent of the days in the English River and South Branch Potomac River simulations, recharge equaled soil2gw_max. That means the soil-profile water excess supplied the only flow on those days to the ground-water reservoir.

Seasonal and episodic DSS values greatly influence CSS values in some instances. Unique events that result in high DSS can skew the significance of long-term trends measured by CSS values. A longer or different simulation/analysis period could indicate different parameter sensitivities.

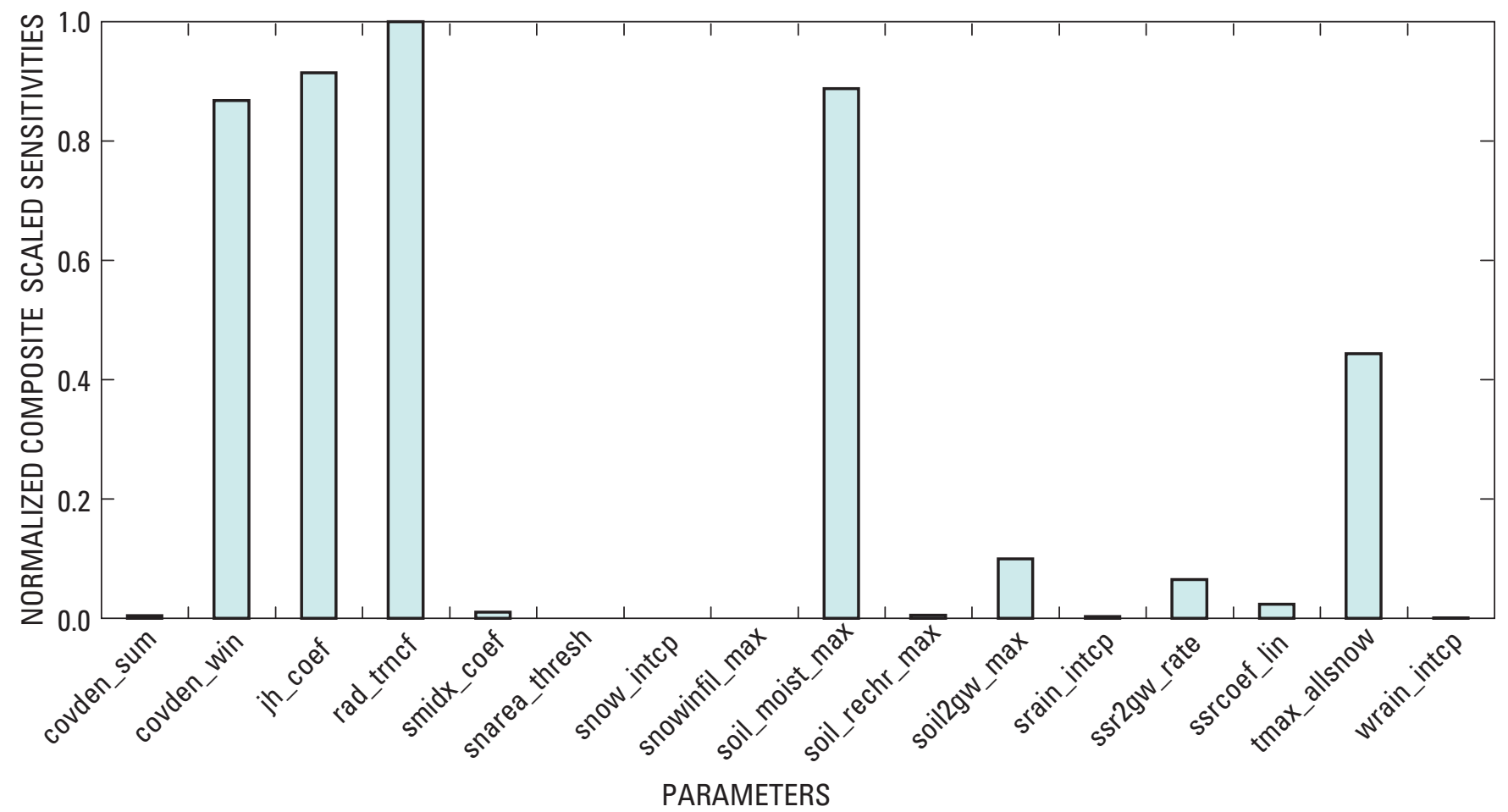

Figure 8. Normalized composite scaled sensitivities of model parameters for the Hamden watershed, Minnesota. 


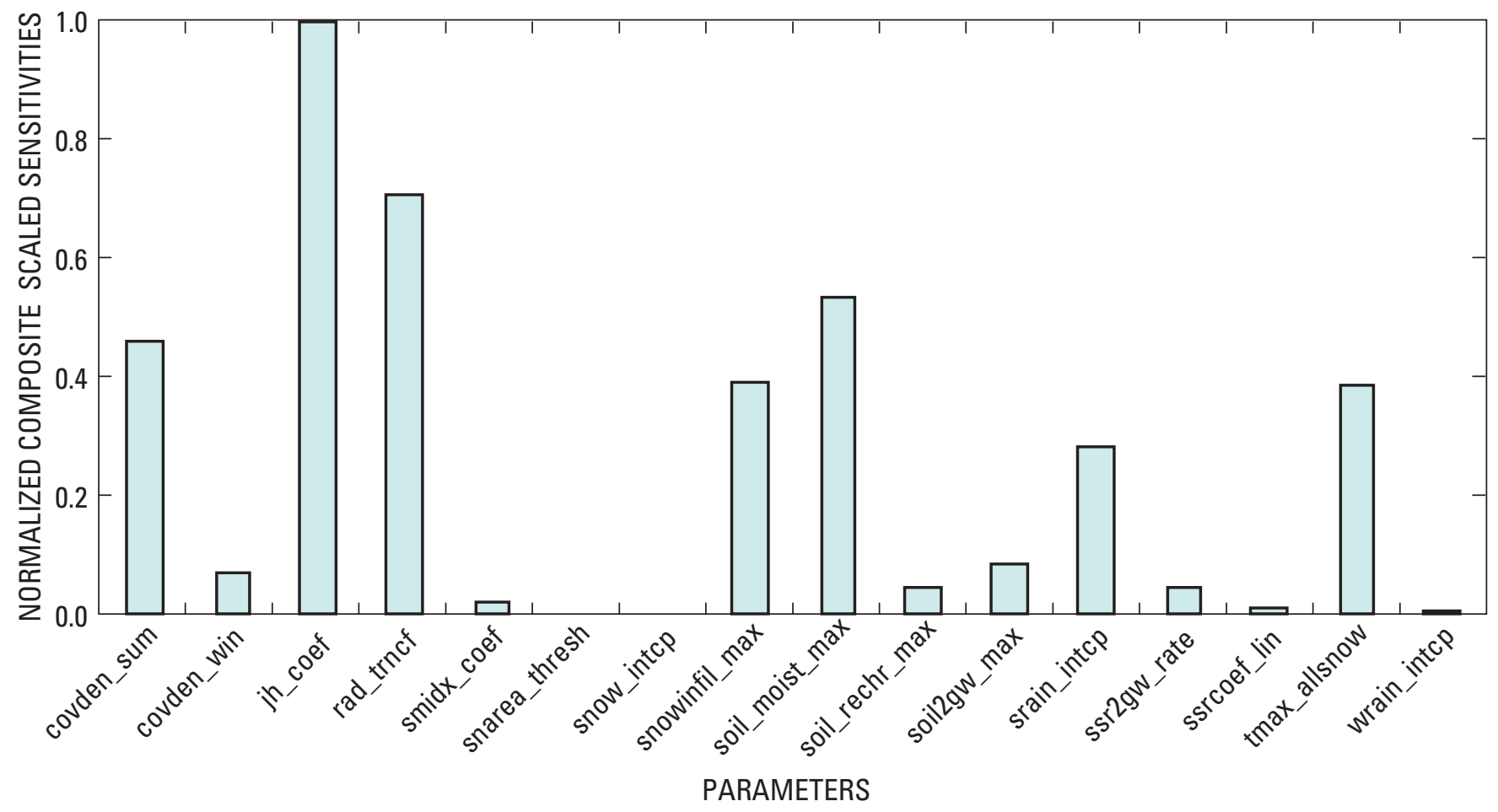

Figure 9. Normalized composite scaled sensitivities of model parameters for the North Fork Pheasant Branch watershed, Wisconsin.

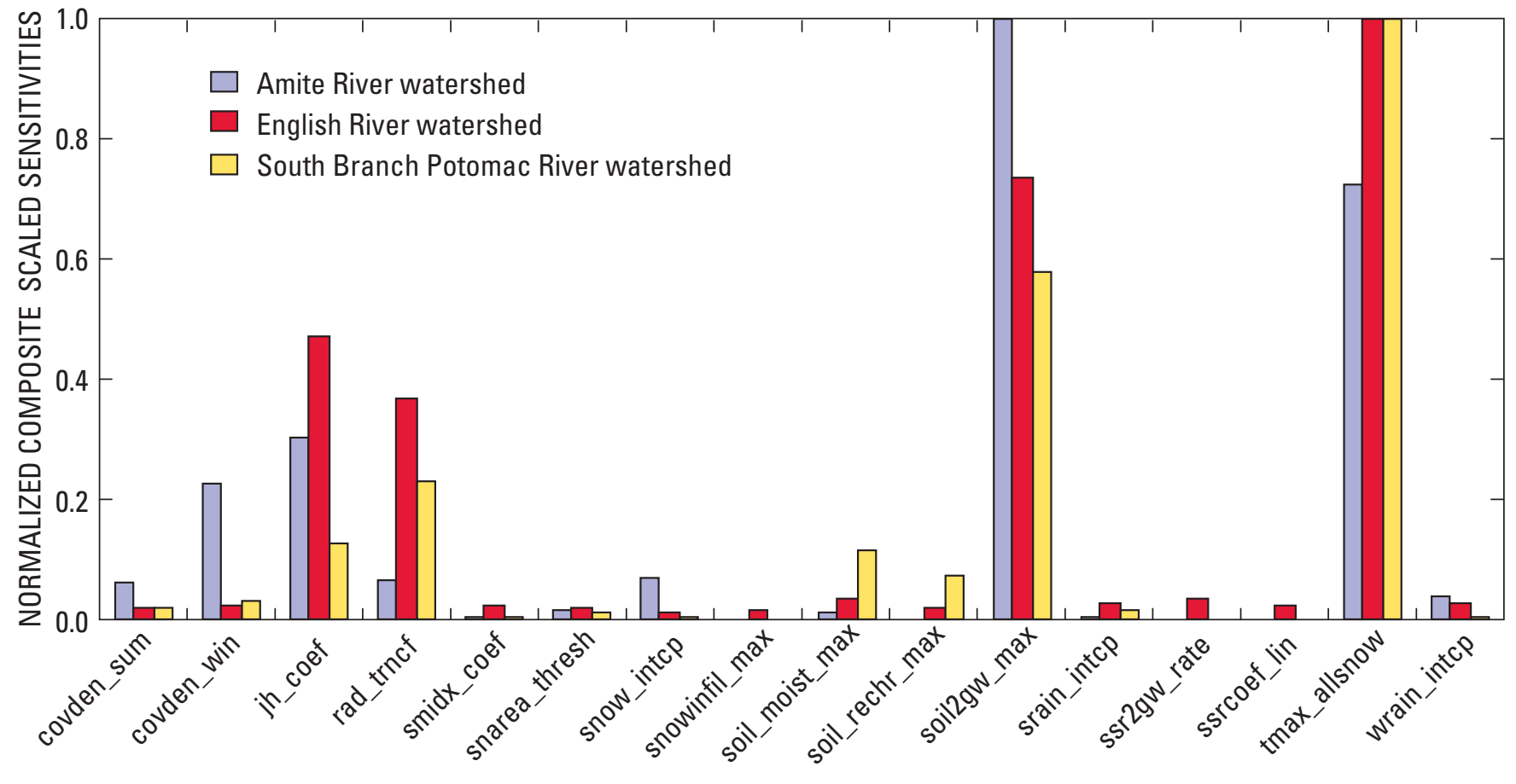

PARAMETERS

Figure 10. Normalized composite scaled sensitivities of model parameters for the Amite River watershed, Louisiana and Mississippi; English River watershed, lowa; and South Branch Potomac River watershed, West Virginia. 


\section{Application of Results to Future Modeling Efforts}

A primary objective of this study was to identify, by geographic region, parameters important to the simulation of ground-water recharge. This objective was partially achieved. During specific periods, whether those periods are days, weeks, or months, specific parameters control the rate of recharge. In the seven watershed models, some of these important parameters indicate the role of climate and physiographic setting. In the Lost River and Big Creek watersheds and the three MOPEX watersheds, simulated recharge (and streamflow) was sensitive to small changes in air temperature. Periods of high precipitation include those periods in late autumn and early winter when temperatures are near the freezing point. In the North Fork Pheasant Branch watershed, the rate of recharge is limited in summer because most of the precipitation is lost to ET, but is greater in autumn and winter when ET is minimal. Parameters related to the density of tree cover in the summer and winter also affected recharge in that watershed.

Although the other study objectives were considered secondary, their results proved valuable to the development of future models. The value of a rigorous sensitivity analysis can (1) make the calibration process more efficient, (2) guide additional data collection, (3) identify model limitations, and (4) explain simulated results.

\section{Improve Calibration Efficiency}

The standard version of PRMS has more than 125 parameters. Some of the empirical formulas alone contain four parameters. The abundance of model parameters can seem overwhelming to an inexperienced watershed modeler and daunting to even the most knowledgeable. Automated calibration of process-based watershed models is becoming increasingly popular and provides capabilities that help modelers take greater advantage of available data (Poeter and Hill, 1998). Several methods use multiple objective functions to calibrate the model's simulation of streamflow and hydrograph shape (Boyle and others, 2000; Hogue and others, 2000) or streamflow and solar radiation, potential ET, and water balance (L.E. Hay, U.S. Geological Survey, written commun, 2005). The ability to identify the 2 or 5 or even 10 parameters most important to the simulation would greatly increase the efficiency of the calibration process.

Hill (1998) describes 14 methods and guidelines for effective model calibration, and several define the role of scaled sensitivities. Guideline 1 in Hill (1998), "Apply the principle of parsimony," states the importance of beginning the calibration by estimating very few parameters and increasing complexity slowly. Completing a systematic sensitivity analysis before final model calibration would clearly identify parameters that have dominant control over the simulated results. The extra effort could eliminate over-parameterization and an ineffective approach toward calibration.

\section{Guide Data Collection}

Nonlinear regression can be used directly to guide datacollection efforts. Tiedeman and others (2003) discussed the "value of improved information" (VOII) method to determine the model parameters most important to a given prediction. Data then can be collected about the flow-system features related to those parameters. Although the VOII method was beyond the scope of this study, the scaled sensitivities can be used in their most basic form to guide data collection. Simply, if the model is sensitive to a parameter, or a group of parameters, resources could be allotted to collect data on the most sensitive parameters and thereby efficiently reduce model uncertainty. Some of the parameters used in PRMS are physically based and can be measured in the field, such as tree-cover density, but most others are coefficients or maximum rates that partition or limit flow among the reservoirs. Parameters such as soil2gw_max or jh_coef cannot be measured in the field, but a high CSS would indicate that they warranted additional consideration. The type of sensitivity analysis detailed in this study could intimate which parameters could be set to default values (low CSS) and which parameters would require a more thorough investigation (high CSS).

\section{Identify Model Limitations}

A hydrologic flow model represents a complex, natural system with a set of mathematical equations that describe the system. Intrinsic to the model is the error and uncertainty associated with approximations, assumptions, and simplifications that must be made (Ely and Kahle, 2004). Sources of hydrologic modeling errors typically are (1) input data, (2) representation of physical processes by model algorithms, and (3) parameter estimation during the calibration procedure (Troutman, 1985). A rigorous sensitivity analysis helps identify the major source of errors.

A strength of PRMS and MMS is the modular nature of the code. A computer model could be customized to match the specific purpose and scope of a project by adding or deleting routines. The objective of the Hamden watershed model was to investigate wetland features. Modules were compiled to route flow to land-surface features first, limiting flow to the ground-water reservoir. A watershed model in a similar setting, but without the wetland emphasis, would most likely yield significantly different results. In the mountainous watersheds of Washington State, the importance of snowmelt created the need for an additional parameter, groundmelt, to define the amount of snowpack that could infiltrate the soil. This parameter also may have been important in other 
snow-driven watersheds, such as North Fork Pheasant Branch or Hamden. The PRMS code used for the three MOPEX watershed models was identical and was reflected, in part, by the similarity of the parameter sensitivities of the Amite River, English River, and South Branch Potomac River watershed models.

\section{Explain Simulated Results}

Watershed models traditionally are calibrated using measured streamflow data as calibration targets. Some models benefit by the existence of a long period of record to constrain the model. Studies such as MOPEX and the International Association of Hydrologic Studies' Predictions in Ungaged Basins are investigating methods to estimate a priori model parameters and reduce parameter uncertainty for watersheds with no streamflow measurements or other data to calibrate a model. An effort could be made to validate the simulation results by using available diagnostic statistics, such as DSS and CSS. Merely minimizing residuals between simulated and measured streamflow does not ensure that the flow processes in a watershed are properly simulated.

An examination of parameter sensitivities may provide information about why a model produces certain results. For example, is the scaled sensitivity a function of the parameter value, the modeling and calibration approach, or climatic limitations? The modeler can evaluate the parameter sensitivities and determine if the simulated model output is correct for the right reasons. In short, do the parameters with the highest and lowest CSS make hydrologic sense? If not, the model construction and calibration should be reconsidered.

\section{Summary}

Recharge is a vital part of the ground-water budget. As competition grows for limited water resources, water managers increasingly look to the ground-water system as a source for possible development. Most available methods to estimate ground-water recharge depend on data that are generally unavailable or difficult to obtain. Methods are also limited by the application of scale. Methods either simulate at a point or site scale or simulate a large area as a single value, thereby limiting the ability to accurately scale down to a local area or distribute the recharge estimates spatially.

Process-based models that compute distributed water budgets on a watershed scale have demonstrated an ability to calculate accurately recharge rates at varying scales using readily available databases. These watershed models should be evaluated to determine what parameters have a dominant control of the estimated recharge rates.

The U.S. Geological Survey analyzed the sensitivity of estimated ground-water recharge to parameters in seven existing watershed models in different humid regions of the United States to gain an understanding of the watershed- model parameters that control recharge estimates. A nonlinear regression model, UCODE, was coupled with the Modular Modeling System and Precipitation-Runoff Modeling System to generate a suite of diagnostic statistics. Dimensionless scaled sensitivities, composite scaled sensitivities, and parameter correlation coefficients tested the sensitivity of simulated recharge to parameter values and the ability of two parameters to be uniquely estimated. The objectives of the study were to determine (1) which watershed-model parameters were the dominant controls in determining recharge, (2) if regional differences existed in the sensitivity of recharge to watershed-model parameters, (3) if specific computer models used to simulate recharge affect parameter sensitivities, and (4) if objectives and approach of a study can affect ground-water recharge estimates and parameter sensitivities.

Simulated recharge in the Lost River and Big Creek watersheds, in Washington State, was sensitive to small changes in air temperature. The precipitation falls predominantly as snow, and the spring snowmelt produces much of the recharge and streamflow. A change of 0.3 degree Fahrenheit in the simulated maximum daily temperature would affect the form of precipitation (rain or snow) on 20 days in the Lost River watershed and 25 days in the Big Creek watershed over the 3-year simulation period.

The model for the Hamden watershed, in west-central Minnesota, was developed to investigate the relations that wetlands and other landscape features have with runoff processes. Different modules for wetlands were compiled to achieve this objective. Excess soil moisture was preferentially routed to wetlands instead of to the ground-water system, resulting in very little sensitivity of any parameters to recharge.

Recharge in the North Fork Pheasant Branch watershed, Wisconsin, was most sensitive to parameters related to evapotranspiration (ET). Recharge occurs during winter and spring, when snow is melting, or during autumn, when ET is reduced. Recharge is limited in summer, when ET is greatest.

Three watersheds were simulated as part of the Model Parameter Estimation Experiment (MOPEX). Amite River near Denham Springs, Louisiana; English River at Kalona, Iowa; and South Branch Potomac River near Springfield, West Virginia, serve as benchmark watersheds to address the parameter uncertainty of ungaged watersheds and assess new techniques to decrease the uncertainty. Parameter sensitivities for the three MOPEX watersheds were remarkably similar. Tmax_allsnow and soil2gw_max, a user-defined flow-routing parameter, were the dominant controls for recharge.

Although the primary objective of this study was to identify, by geographic region, parameters important to ground-water recharge simulation, the secondary objectives proved to have valuable applications in developing future models. The value of a rigorous sensitivity analysis can (1) make the calibration process more efficient, (2) guide additional data collection, (3) identify model limitations, and (4) help explain simulated results. 


\section{References Cited}

Bauer, H.H., and Vaccaro, J.J., 1987, Documentation of a deep percolation model for estimating ground-water recharge: U.S. Geological Survey Open-File Report 86-536, 180 p.

Boyle, D.P., Gupta, H.V., and Sorooshian, S., 2000, Toward improved calibration of hydrologic models: Combining the strengths of manual and automatic methods: Water Resources Research, v. 36, no. 12, p. 3663-3674.

Cherkauer, D.S., 2004, Quantifying ground water recharge at multiple scales using PRMS and GIS: Ground Water, v. 42, no. 1, p. 97-110.

Christiaens, K., and Feyen, J., 2002, Use of sensitivity and uncertainty measures in distributed hydrological modeling with an application to the MIKE SHE model: Water Resources Research, v. 38, no. 9, p. 8.1-8.15.

Downer, C.W., and Ogden, F.L., 2003, Prediction of runoff and soil moistures at the watershed scale-Effects of model complexity and parameter assignment: Water Resources Research, v. 39, no. 3, p. 1.1-1.13.

Drost, B.W., Ely, D.M., and Lum, W.E., III, 1999, Conceptual model and numerical simulation of the ground-water-flow system in the unconsolidated sediments of Thurston County, Washington: U.S. Geological Survey Water-Resources Investigations Report 99-4165, 254 p.

Ely, D.M., 2003, Precipitation-runoff simulations of current and natural streamflow conditions in the Methow River Basin, Washington: U.S. Geological Survey Water-Resources Investigations Report 03-4246, 35 p.

Ely, D.M. and Kahle, S.C., 2004, Conceptual model and numerical simulation of the ground-water-flow system in the unconsolidated deposits of the Colville River Watershed, Stevens County, Washington: U.S. Geological Survey Scientific Investigations Report 2004-5237, 72 p.

Ely, D.M. and Risley, J.C., 2001, Use of a precipitation-runoff model to simulate natural streamflow conditions in the Methow River Basin, Washington: U.S. Geological Survey Water-Resources Investigations Report 01-4198, 36 p.

Healy, R.W., 1990, Simulation of solute transport in variably saturated porous media with supplemental information modifications to the U.S. Geological Survey's computer program VS2D: U.S. Geological Survey Water-Resources Investigations Report 90-4025, 125 p.

Healy, R.W., and Ronan, A.D., 1996, Documentation of computer program VS2DH for simulation of energy transport in variably saturated porous media-Modification of the U.S. Geological Survey's computer program VS2DT: U.S. Geological Survey Water-Resources Investigations Report 96-4230, 36 p.

Hill, M.C., 1998, Methods and guidelines for effective model calibration: U.S. Geological Survey Water-Resources Investigations Report 98-4005, 90 p.
Hogue, T.S., Sorooshian, S., Gupta, H.V., Holz, A., and Braatz, D.T., 2000, A multi-step automatic calibration scheme for river forecasting models: Journal of Hydrometeorology, v. 1, p. 524-542.

Hunt, R.J., Steuer, J.J., and Bullen, T., 2001, Delineating a recharge area for a spring using numerical modeling, Monte Carlo techniques, and geochemical investigations: Ground Water, v. 39, no. 5, p. 702-712.

Lappala, E.G., Healy, R.W., and Weeks, E.P., 1987, Documentation of computer program VS2D to solve the equations of fluid flow in variably saturated porous media: U.S. Geological Survey Water-Resources Investigations Report 83-4099, 184 p.

Leavesley, G.H., Lichty, R.W., Troutman, B.M., and Saindon, L.G., 1983, Precipitation-runoff modeling system-User's manual: U.S. Geological Survey Water-Resources Investigations Report 83-4238, 207 p.

Leavesley, G.H., Restrepo, P.J., Markstrom, S.L., Dixon, M., and Stannard, L.G., 1996, The modular modeling system (MMS)_User's manual: U.S. Geological Survey Open-File Report 96-151, 200 p.

Lee, K.K., and Risley, J.C., 2002, Estimates of ground-water recharge, base flow, and stream reach gains and losses in the Willamette River Basin, Oregon: U.S. Geological Survey Water-Resources Investigations Report 01-4215, 52 p.

Martinez, J.E., Duchon, C.E., and Crosson, W.L., 2001, Effect of the number of soil layers on a modeled surface water budget: Water Resources Research, v. 37, no. 2, p. 367-378.

Mastin, M.C., and Vaccaro, J.J., 2002, Watershed models for decision support in the Yakima River Basin, Washington: U.S. Geological Survey Open-File Report 02-404, 48 p.

Poeter, E.P., and Hill, M.C., 1997, Inverse models: A necessary next step in ground-water modeling: Ground Water, v. 35, no. 2, p. 250-260.

Poeter, E.P., and Hill, M.C., 1998, Documentation of UCODE, a computer code for universal inverse modeling: U.S. Geological Survey Water-Resources Investigations Report 98-4080, 116 p.

Rorabaugh, M.I., 1964, Estimating changes in bank storage and groundwater contribution to streamflow: International Association of Scientific Hydrology Publication 63, p. 432-441.

Rutledge, A.T., 1998, Computer programs for describing the recession of ground-water discharge for estimating mean ground-water recharge and discharge from streamflow records-Update: U.S. Geological Survey Water-Resources Investigations Report 98-4148, 43 p.

Rutledge, A.T., and Daniel, C.C., 1994, Testing an automated method to estimate ground water recharge from streamflow records: Ground Water, v. 32, no. 2, p. 180-189. 
Samanta, S., and McKay, D.S., 2003, Flexible automated parameterization of hydrologic models using fuzzy logic: Water Resources Research, v. 39, no. 1, p. 1.1-1-13.

Scanlon, B.R., Healy, R.W., and Cook, P.G., 2002, Choosing appropriate techniques for quantifying ground-water recharge: Hydrogeology Journal, v. 10, no. 1, p. 18-39.

Simunek, J., Sejna, M., and van Genuchten, M. Th., 1999, The HYDRUS-2D software package for simulating twodimensional movement of water, heat, and multiple solutes in variably saturated media. Version 2.0, IGWMC - TPS - 5: Golden, Colo., International Ground Water Modeling Center, Colorado School of Mines, $251 \mathrm{p}$. Steuer, J.J., and Hunt, R.J., 2001, Use of a watershedmodeling approach to assess hydrologic effects of urbanization, North Fork Pheasant Branch Basin near Middleton, Wisconsin: U.S. Geological Survey Water-Resources Investigations Report 01-4113, 49 p.

Tiedeman, C.R., Hill, M.C., D’Agnese, F.A., and Faunt, C.C., 2003, Methods for using groundwater model predictions to guide hydrogeologic data collection, with application to the Death Valley regional groundwater flow system: Water Resources Research, v. 39, no. 1, p. 5.1-5.17.
Troutman, B.M., 1985, Errors and parameter estimation in precipitation-runoff modeling 2. Case Study: Water Resources Research, v. 21, no. 8, p. 1214-1222.

Vogel, R.M., and Sankarasubramanian, A., 2003, Validation of a watershed model without calibration: Water Resources Research, v. 39, no. 10, p. 7.1-7.9.

Woodward, D.G., Packard, F.A., Dion, N.P., and Sumioka, S.S., 1995, Occurrence and quality of ground water in southwestern King County, Washington: U.S. Geological Survey Water-Resources Investigations Report 92-4098, 69 p., 4 pl.

Yobbi, D.K., 2000, Application of nonlinear least-squares regression to ground-water flow modeling, West-Central Florida: U.S. Geological Survey Water-Resources Investigations Report 00-4094, 58 p. 
Manuscript approved for publication, February 9, 2006

Prepared by the Enterprise Publishing Network,

Publishing Service Center, Tacoma, Washington

Bill Gibbs

Debra Grillo

Sharon Wahlstrom

For information concerning the research in this report, contact the the Washington Water Science Center Director,

U.S. Geological Survey, 1201 Pacific Avenue - Suite 600

Tacoma, Washington 98402

http://wa.water.usgs.gov 


$$
\text { 总 }
$$

